\title{
State Ownership and Control in the Czech Republic
}

\author{
Evžen Kočenda \\ Jan Hanousek
}

CESIFo Working PAPER No. 2801

CAtegory 2: Public CHOICE

SEPTEMBER 2009

\footnotetext{
An electronic version of the paper may be downloaded

- from the SSRN website:

- from the RePEc website:

- from the CESifo website: 


\title{
State Ownership and Control in the Czech Republic
}

\begin{abstract}
We analyze the extent of the integrated control of the state over privatized firms during the post-privatization decade (1995-2005) in the Czech Republic. During this period the integrated control potential of the state resembled a corporate pyramid. While pyramidal control was not fully utilized, the golden share in the hands of the state substantially enhanced its ability to control firms. In terms of corporate performance we show that state control resulted in declining and even negative corporate performance. Integrated state control was shown to be mostly inferior when compared with private types of ownership. State ownership positions are in striking contrast with the lack of capacity to push corporate performance in order to collect larger tax volumes. Lack of focus and inter-agency cooperation as well as the simple inefficiency of the state bureaucracy are the most likely reasons behind our findings.
\end{abstract}

JEL Code: C30, D21, D29, G30, L21.

Keywords: state ownership, control, corporate performance, privatization.

\author{
Evžen Kočenda \\ $C E R G E-E I$ \\ Politickych veznu 7 \\ P.O. Box 882 \\ 11121 Prague \\ Czech Republic \\ evzen.kocenda@cerge-ei.cz
}

\author{
Jan Hanousek \\ CERGE-EI \\ Politickych veznu 7 \\ P.O. Box 882 \\ 11121 Prague \\ Czech Republic \\ jan.hanousek@cerge-ei.cz
}

A substantial part of this paper was written while Evžen Kočenda was a Visiting Fellow at the Center for Economic Studies (CES) at the University of Munich, whose hospitality is warmly acknowledged. We are grateful to Lucy Chernykh, Iraj Hashi, and presentation participants at CES (Munich, 2009) and 8th International Conference - Challenges for Europe (Split, 2009) for valuable comments. Financial support from GAČR grant No. 402/09/1595 is gratefully acknowledged. The usual disclaimer applies. 


\section{Introduction and Motivation}

La Porta, Lopez-de-Silanes and Shleifer (1999) show that the ownership structure of vertically organized companies, known as corporate pyramids, are widespread around the world. However, these structures are more often present in emerging markets (Khanna and Yafeh, 2007). Morck (2009) highlights that it is the power of pyramids, which is disguised to outside observers. Most of the literature on the topic considers a wealthy family at the top of the pyramid, while much less attention has been paid to the state as the ultimate owner (see Morck, Wolfenzon and Yeung, 2005). We present evidence of the state being in control within a corporate pyramid in an emerging economy with a web of seemingly private companies. Our detailed analysis of the data shows that the direct control of the state was significant and was further enhanced via golden share holdings. However, we find that integrated state control had a detrimental effect on corporate performance, which declined over time and became negative. We conclude that integrated state control was not effectively used by the state, a finding that indicates the inefficiency of a state bureaucracy. Although the amount of state control is significant in the data, we do not find evidence of integrated state control employed to an extent similar to corporate structures in Russia or China.

The integrated control of the state may evolve from having direct control through a majority voting right, and increase with the increased influence of having a golden share, to the institution of a complex control structure like an ownership pyramid. In general, a corporate pyramid is a group of firms whose ownership structure follows a topto-bottom direction of control, where the ultimate owner is at the top and exerts its control over firms at successive lower levels. This fractal-like pattern of ownership can proliferate to several levels.

Thus the key characteristics of a corporate pyramid are ownership and control, which lends the ultimate owner leveraged power over minority shareholders. Already in 1932 Berle and Means had pointed to the existence of a great discrepancy present in corporate pyramids between the ultimate owner's control and cash-flow rights. These control rights are typically high due to the controlling devices described in the previous paragraphs, while cash-flow rights may be considerably lower as articulated in Bebchuk, Kraakman and Triantis (2000). Traditionally it is assumed that pyramids are formed to 
allow the ultimate owner to achieve control over a firm by using only a small cash flow stake. This arrangement inevitably leads to less-than-efficient corporate governance and associated agency problems. Further reasons for the existence of pyramidal groups include the limited liability of separately registered groups, more space for the promotion of managers to top positions as well as better monitoring of managers, and the provision of capital under favorable conditions to other firms within the structure (Morck, Wolfenzon and Yeung, 2005). However, despite the ubiquity of pyramidal business groups, no formal theory explains their existence (Almeida and Wolfenzon, 2006).

It is frequently assumed that the disparity stemming from the ownership and control characteristics of the pyramid combined with inadequate institutions and market regulations produce in many emerging markets conditions favorable to the expropriation of minority shareholders, also known as "tunneling". ${ }^{1}$ However, despite the almost axiomatic nature of the link between pyramids and minority shareholders' expropriation in the literature, Khanna and Yafeh (2007, p. 346) argue that the link is unjustifiable since "the empirical evidence on the prevalence and severity of profit tunneling from minority shareholders within pyramidal groups is far from clear-cut".

In most cases the literature concentrates on a wealthy family at the top of a pyramid. While various effects of pyramidal structures on corporate performance, firm value, etc. are considerably researched in the literature (see Morck, Wolfenzon and Yeung, 2005 for a survey), a pyramidal structure with the state at the top of the control chain is under-researched. Existing studies report a significant presence of the state in European firms (La Porta, Lopez-de Silanes and Shleifer, 1999; Faccio and Lang, 2002), whose control potential further increases when direct control is augmented by control through golden shares (Bortolotti and Faccio, 2006). The literature on the extent of state control in the pyramidal framework in transformation economies is scarce, but for example Chernykh (2008) provides evidence for a dramatically high level (37-48\%) of state control over the sampled Russian firms. In China, Ma, Yao and Xi (2006) describe the emergence of business groups in which a state-owned firm as the largest shareholder can exert power over the rest of the companies in a business group. The formation of

\footnotetext{
${ }^{1}$ The term "tunneling" can be traced to the expropriation of minority shareholders following large-scale privatization in the Czech Republic and became widespread in the literature due to Johnson, La Porta, Lopez-de Silanes and Shleifer (2000).
} 
these pyramid-like corporate structures was intentional to allow the state extensive control.

The identification of the extent of integrated state control is important because the state as ultimate owner can exert great political influence over the economy because the political influence is proportional to the extent of control and not to the extent of owned property (Morck, Stangeland, and Yeung, 2000; Morck and Yeung, 2004). The case of state ultimate ownership multiplies the control over a vast array of assets in combination with extensive political influence. A government formed by a strong party or coalition can then tap into extensive resources to finance re-election. Such an advantage may be dangerous in countries with less developed institutions and legal frameworks as it might yield to corruption and the misuse of assets. The power of the state to intervene in the economy and distribute regulatory and legal advantages to specific firms is well analyzed on a large set of transition economies by Hellman, Jones, and Kaufmann (2003).

This identification is also important due to the potential negative effects stemming from the conflict between political costs and agency costs (Shleifer and Vishny, 1994; Qian, 1996). For example, following other-than-economic objectives, firms with state control are less likely to innovate and restructure their line of production, as evidenced by Frydman, Hessel, and Rapaczynski (2006), or firms often intentionally delay restructuring (Bennett, Estrin, and Maw, 2005). Finally, soft budget constraints can be practiced between state-controlled credit providers and firms because they are hidden by less-than-evident links among firms and financial institutions under state control (Hanousek and Kočenda, 2008). Preferential treatment of state-controlled firms by statecontrolled financial intuitions constitutes the emergence of a subsidy, whose effects in firms in Central Europe are shown in Frydman, Gray, Hessel, and Rapaczynski (2000).

In this paper we contribute to the literature by analyzing the extent of integrated state control, including a state pyramid, as well as the effects of this control on corporate performance. Integrated state control can emerge as a result of extensive privatization that leaves distinctive footprints on the performance of newly privatized firms, an issue that is extensively reviewed by Estrin, Hanousek, Kočenda, and Svejnar (2009) and that has occurred in numerous countries. Such an arrangement appeared in the Czech Republic, where industrial holding companies emerged out of the former centrally- 
planned units, sometimes with 15-30 horizontally and vertically linked plants and subsidiaries. ${ }^{2}$ These companies were voucher-privatized and restructured using government subsidies. The remaining shares were bought at a discount by the new management teams and consortia of Czech banks. Voucher privatization led to the creation of large, diversified investment funds, often indirectly run by banks, which control linked enterprises (Khanna and Yafeh, 2007). The switch from a command to a market economic system has provided a unique opportunity to study the behavior of the state in the role of the ultimate owner at the top of a pyramid.

The paper is structured as follows. First, we briefly describe the privatization program and data in Sections 2 and 3. Then we proceed with an analysis of the true extent of integrated state control in Section 4. We present evidence of the effects of state control on corporate performance in Section 5. In the concluding section we summarize our findings and chart potential further research.

\section{Privatization Program}

After the "velvet revolution" in 1989, the Czech Republic emerged from their centrallyplanned economy to re-instate a market economy and democracy. A massive privatization program was administered in the Czech Republic in the first half of the 1990s under three different schemes: restitution, small-scale privatization, and large-scale privatization. We only reiterate the main aspects of the Czech privatization that are relevant for this study since the process has been extensively described in the literature, e.g., Hanousek and Kroch (1998) and Kočenda (1999). The first two schemes began in 1990 and were most important during the early years of the transition. Large-scale privatization, by far the most important scheme, began in 1991, was completed in early 1995 , and allowed for various privatization techniques. Small firms were usually auctioned off or sold in tenders. Many medium-sized businesses were sold in tenders or to predetermined buyers in direct sales. Most large and many medium-sized firms were transformed into joint stock companies and their shares were distributed through voucher privatization (almost one-half of the total number of all the shares of all joint stock

\footnotetext{
${ }^{2}$ Cull, Matesova, and Shirley (2002) describe control pyramids in the Czech Republic.
} 
companies were privatized in the voucher scheme), sold in public auctions or to strategic partners, or transferred to municipalities. ${ }^{3}$

The voucher scheme was part of the large-scale privatization process. Two waves of voucher privatization took place, in 1992-93 and 1993-94. Both waves were administered in the same manner and there were no differences in their set-up. During the scheme, a total of 1664 firms were privatized: 988 in the first wave and 676 in the second wave; from this number 185 firms were privatized in both waves in various proportions of their assets. All Czech citizens over the age of 18 who resided in the Czech Republic could participate in the voucher process. For each wave every eligible citizen was authorized to buy a voucher book that contained 1000 investment "points" for 1000 Czech crowns (CZK), about a week's wage. Before the privatization started, individuals had the option of assigning none, some, or all of their points to Privatization Investment Funds (PIFs): newly established financial firms vaguely similar in their scope of activity to closed-end mutual funds. ${ }^{4}$ Aggarwal and Harper (2000) persuasively document that share valuation and demand in the early stage of this auction were based on firm characteristics (return on sales, sales growth) and ownership structure. Share prices and trading volumes from prior rounds increased in importance as determinants in later stage of the auction, though.

At the beginning it was the Ministry of Privatization that executed the privatization process. The privatization authorities had rough goals regarding how much property they wanted to include in the voucher program, and hence how much control should stay with the state. To administer the property that remained in the state's possession, the National Property Fund (NPF) was established as a state institution that

\footnotetext{
${ }^{3}$ The method of the privatization of each state-owned firm was decided on the basis of an officially accepted privatization project. According to the law, all state-owned enterprises were selected for either the first or the second privatization wave, or they were temporarily exempted. Each selected firm had to submit an official privatization proposal that was usually crafted by the firm's management under the tutelage (and responsibility) of its sectoral ministry. Any domestic or foreign corporate body or individual was allowed to present a competing project that was to be considered on an equal footing with the official one.

${ }^{4}$ The regulation of PIFs evolved gradually through Decree no. 383/1991, its Amendment No. 62/1992, and Act No. 248/1992. The most important clauses restricted each privatization fund from investing more than $10 \%$ of the points acquired in the voucher scheme in a single company and obtaining in exchange more than $20 \%$ of the shares in any company. Privatization funds established by a single founder were allowed to accumulate up to $40 \%$ of shares in a given company, but this cap was later reduced to $20 \%$. Many privatization funds circumvented the cap through mergers. The Act also prohibited PIFs founded by financial institutions from purchasing the shares of other financial institutions to prevent excessive concentration of financial capital (for details see Kotrba and Svejnar, 1994).
} 
was entitled with legal power to exercise property rights over companies that were fully or partially owned by the state. By the end of the scheme in 1994 the NPF held on average about a $25 \%$ stake in privatized firms, but the extent varied greatly. The NPF was dissolved at the end of 2005 and the remaining agenda was transferred to the Ministry of Finance. ${ }^{5}$ In our analysis we uncover the true extent of state control over the seemingly private economy resulting from this privatization procedure.

\section{Data and Control in the Pyramid}

We have assembled a large data set on the extent of ownership in a large sample of Czech firms over the period 1996-2005. The beginning of our data sample starts one year after the privatization scheme officially ended (February 1995). The end of our sample coincides with the end of the NPF as an institution. The data come from the archives of the NPF, the former Ministry of Privatization, the Prague Stock Exchange, the Center for Securities in Prague, the commercial database Aspekt, and the Commercial Register of the Czech Republic. For all the firms in our sample we also precisely identify their ownership structure. Therefore we are working with a uniquely large sample of firms that is near the total population of medium-sized and large firms in the economy. More detailed information on the sample size in each period is provided in Section 4 along with our results on the extent of state control.

From our data we are able to isolate the specific extent of ownership represented by the state corporate pyramid as well as distinguish various means of state direct and indirect control and the amount of assets under control. In this respect we are able to trace the development of state control in a number of firms and also control over their assets over time.

The interrelated ownership structure within the state pyramid is illustrated in Figure 1. On the top layer we identify three main institutions through which the state is able to execute control. The key institution is the National Property Fund (NPF) that was set up to administer the property that remained in the hands of the state after the privatization scheme was concluded. Municipalities received various ownership stakes as free property transfers and became stakeholders in numerous companies, mainly in

\footnotetext{
${ }^{5}$ Hanousek and Kočenda (2008) provide additional details.
} 
utilities and transportation. In many firms the stakes of municipalities were parallel with the stakes of the NPF. Finally, other state agencies became stakeholders in firms where the state needed to protect its interests. The description of the multiple presence of the state via different authorities is similar to that in Russia where Chernykh (2008) finds that federal as well as regional governments participate extensively in traded companies. A similar situation exists in China, where the state induced the emergence of business groups in state-owned sectors that have much in common with the classical corporate pyramid. These structures possess control over subsidiary companies and serve as government instruments to facilitate ownership reform and economic transformation as discussed in Ma and $\mathrm{Lu}$ (2005) and Yiu, Bruton and $\mathrm{Lu}(2005)$.

The next layer down shows industrial and financial businesses in which the state is an owner. These are standard industrial, manufacturing or trading companies labeled as firms, various financial institutions labeled as banks, and privatization investment funds specifically set up during the privatization scheme labeled as investment funds. The ownership rights of the state with respect to the businesses in the three categories are denoted by directional arrows. As a general rule, the NPF and municipalities had stakes in firms and banks but not in investment funds. Other state agencies had stakes exclusively in firms.

The lowest layer allows us to begin unveiling the extent of the state pyramid. As a general rule firms own stakes in other firms but do not own stakes in banks or investment funds. This is a result of the post-privatization arrangements and does not have any natural economic rationale behind it. Although some ownership links do exist that go against this rule, we do not consider them in our stylized picture in order to keep it lucid. However, we do consider them when computing ownership shares below. A further result of the privatization scheme is the dominant presence of banks in investment funds because it was primarily banks that established the investment funds as a tool to acquire ownership stakes in privatized firms. Stakes of investment funds in banks are less frequent and have developed over time through the process of investment funds rearranging their portfolios. Both banks and investment funds own stakes in firms as a rule, either directly or indirectly. The indirect link of a bank having a stake in firm through an investment fund is more common than the bank being in the middle. 
Arrows pointing from banks and investment funds towards firms at the top (first) and lowest (third) levels denote the potential of cross ownership: control in the third-level firm via the first-level firm. Of course, the stylized nature of the arrangement does not preclude the possibility of a stake in a firm on the second level as well.

Formally, we describe the chain of control via voting rights in a manner similar to that developed by Chapelle and Szafarz $(2005,2007)$ who, among others, voiced the idea that direct control by any type of owner could be complemented by additional control rights within a corporate structure like a pyramid. To analyze the full extent of a control mechanism, an integrated ownership right should be constructed. The difference in our approach is that we proceed from the top of the control chain - the apex of the pyramidtoward each firm, while Chapelle and Szafarz $(2005,2007)$ develop their algorithm in the opposite direction, from a firm toward the ultimate owner.

First, let $d_{i j}$ denote the share of direct cash-flow rights that firm $i$ holds in firm $j$. Then the $n$-square matrix $\mathrm{D}=\left(d_{i j}\right)$ represents the direct cross-ownership rights in the data set of $n$ firms. In many cases we do not have information about ownership links below a certain control-right threshold. This is often an indication of dispersed ownership in a firm. We acknowledge this limitation by stating that:

$$
\sum_{i=1}^{n} d_{i j} \leq 1 \text { for } i=1, \ldots, n \text {. }
$$

An integrated ownership via a structure such as a corporate pyramid can be constructed as a sum of all direct and indirect ownership links. Integrated ownership is crucial for the consolidation of the ownership structure and it has strong implications for corporate governance issues, namely effective control and firm behavior. It can be constructed via a matrix approach or by using recursive algorithms.

Using the matrix approach, the matrix of integrated ownership $\mathrm{P}=\left(p_{i j}\right)$ is defined as:

$$
P=\operatorname{diag}\left\{I-\sum_{i=1}^{n} d_{i j}\right\} \sum_{s=1}^{\infty} D^{S}=\operatorname{diag}\left\{I-\sum_{i=1}^{n} d_{i j}\right\}(I-D)^{-1} .
$$

In the above equation the diagonal matrix factor is a necessary scaling factor of $\sum_{s=1}^{\infty} D^{S}=(I-D)^{-1}$ that could otherwise suffer from a double counting of voting rights. In real firm level data we observe various ownership cycles as well as a combination of direct and indirect links of length $s$ that may stretch across several levels or layers as described earlier. For this reason we need a scaling factor rather than a simple summation 
of voting rights to avoid an implausible extent of control greater than one hundred percent.

We suggest measuring the direct control over companies by using a conservative majority threshold of 50\% in accordance with Bebchuk, Kraakman and Triantis (2000) and specify the following ownership-control matrix:

$$
c_{i j}=\left\{\begin{array}{c}
1 \text { if } d_{i j}>0.5 \\
0 \text { if } \exists k \neq i: d_{k j}>0.5 \\
d_{i j} \text { otherwise }
\end{array}\right.
$$

In the above definition we also control for the existence of a majority owner $k$ and this way we eliminate the double counting of controlling stakes. Simply said, in the case of a $50 \%$ majority owner, other stakes have no real controlling power. The rule can be generalized to different controlling thresholds employed in the literature (as in La Porta, Lopez-de-Silanes and Shleifer, 1999) and as such it describes the ownership links in a clear and simple manner. Following the matrix approach we finally define the control extent $P$ of the integrated, or ultimate, owner in a corporate pyramid as:

$$
P=\operatorname{diag}\left\{I-\sum_{i=1}^{n} c_{i j}\right\} \sum_{s=1}^{\infty} C^{S}=\operatorname{diag}\left\{I-\sum_{i=1}^{n} c_{i j}\right\}(I-C)^{-1} .
$$

The above approach is versatile enough to enable analysis of the true extent of control of any type of owner, including that of the state in incompletely privatized companies.

The empirical application of the matrix methodology is extremely demanding since with representative samples of firm level data exceeding several thousand firms and subjects the matrices are very large and their mathematical inversions require large amounts of computer memory and time. In the empirical part of our analysis we therefore implement inverse matrices and compute the integrated ownership via the recursive SQL algorithm described in detail in Bena, Hanousek and Fons-Rosen (2009).

In practice we consider the state to be an owner, at the zero level, in all companies where the state holds equity via the NPF. Being at zero level means that there is no other owner that owns the state. Companies may also have other zero-level owners in cases where the state does not hold a $100 \%$ stake. In this case owners may be truly private entities or another state agency or municipality as shown in Figure 1. Further, we define one-level owners as those who are owned by zero-level owners; in the majority of cases the zero-level owner is the state via the NPF. Two-level owners are those that are owned 
by one-level owners. We also check for cases where a two-level owner may have a zerolevel owner besides a one-level owner(s). We continue this distinction among the ownership levels down to the final potential level (ranging between eight to 12 levels) in a manner similar to Khanna and Yafeh (2007), who consider nine levels. The effect of pyramidal control across various levels is chiefly possible through banks and privatization investment funds (investment companies). A state owning a decisive control stake in a bank is able to exert its control on firms in which the bank holds a substantial stake. Banks own also investment companies that in turn hold shares of other firms. These channels constitute the basis for the pyramidal control of the state.

We follow the approach of La Porta, Lopez-de-Silanes, and Shleifer (1999) and measure the control by total voting rights since control over a company is primarily a matter of voting power. In order to gauge the true control of the state we distinguish two categories of ownership concentration, depending on the number of shares held by the state in privatized companies. In the divisions of stakes that allow for effective control we follow Hanousek, Kočenda, and Svejnar (2007) and use first a 50\% threshold as the law provides important rights of ownership and control for owners with majority ownership (more than $50 \%$ of shares) and it also conforms to the practice in the literature based on International Financial Reporting Standards (IFRS). Simply speaking, a 50\% threshold cannot be contested and in empirical work it also prevents potential miscalculations of two majority owners. The second and less conservative threshold is $25 \%$, which is in line with the relatively high ownership concentration present in Czech firms as well as with the methodological approach by the Bureau Van Dijk (2007, p.18). Still, when using the $25 \%$ threshold we are slightly more conservative than La Porta, Lopez-de-Silanes, and Shleifer (1999), who opt for $20 \%$. When using the $25 \%$ threshold we verify that there is no other owner with an exceeding stake who could override the control of the state.

Besides direct control through voting rights associated with the number of shares held, state control over a firm may also be executed by other means. The most effective one is the "golden" share. ${ }^{6}$ Such an instrument, in the form of a single share with special

\footnotetext{
${ }^{6}$ The golden share was introduced by Act No. 210/1993, modifying Act No. 92/1991. The act set the conditions for property transfer from the state to others with the aim of protecting the special interests of the state in firms privatized in large-scale privatization. The veto rights associated with the golden share
} 
status, allows the state to prevent any major changes in a company where the state holds such a share. ${ }^{7}$ Utility companies are a typical example of state control through the golden share, but not the only example, as the golden share has been part of the ownership structure in other industries as well.

\section{Extent of State Control}

An earlier assessment of the extent of state control over privatized firms was performed by Hanousek and Kočenda (2008) over the period 1994-2005 based on a complete data set on assets as well as the means of control in voucher privatized firms in the Czech Republic. The assessment was performed on the first layer of ownership of the NPF. This means that an assessment of the control over firms where the state had a direct stake through its agency has been made, but pyramidal structure was not considered. The extent of the broadly defined state - that is, including municipalities — was not considered, either. Despite this limitation the state control potential was found to be extensive and certainly larger than has been found by earlier research. The privatized firms became truly private only after the sale of the remaining shares possessed by the state, the liquidation of golden shares and the consequent decline of the direct state control potential.

\subsection{State Control over Firms}

We now turn to providing the results of the analysis that accounted for the pyramidal control of an integrated owner and reporting the extents of control obtained via the matrix methodology described in Section 3. The control potential of the state pyramid is presented in several Tables. ${ }^{8}$ We begin with a simple account and in the first two columns of Table 1, panel A we show the number of firms in which the state, represented by the

usually relate to the scope and line of business activity and depend on each company's charter. When the state sells its golden share, it gives up its rights in the company and the golden share ceases to exist. The instrument of the golden share in the Czech Republic does not conform fully to that found in other countries since it is limited to being solely an instrument of state control and does not serve as a means of attracting free or less expensive credit (Bortolotti and Faccio, 2004).

${ }^{7}$ Chernykh (2008) shows that the Russian state is using this valuable channel to exert its control in numerous companies.

${ }^{8}$ In the Tables describing the level of state control we exhibit numbers for state-controlled firms only, while the remaining sample of privately-held firms without state control is not included. 
National Property Fund, had any voting rights. The number in each year constitutes a hundred percent base for a relative comparison, which is presented in parentheses immediately following the absolute numbers throughout the Table. As the transformation progressed the absolute number of firms with a state presence decreases. In the third column we show that the number of firms that the state controlled directly through its (at least) $50 \%$ majority voting rights decreases over time as well. The relative proportion increases, though. The control ability of the state in the pyramid is essentially the same as its direct control, both in absolute and relative terms. This indicates that control through the pyramid did not deliver control enhancement over direct control. However, the control ability doubles when golden shares are accounted for. In panel B of Table 1 we present the results of the control potential when a $25 \%$ voting-right threshold is considered. As one might expect the direct control of the NPF increases with the less conservative threshold. The increase is considerable during the second half of the 1990's but after 2000 it is only moderate. Pyramidal control is surprisingly not enhanced by the lower threshold. The golden share on other hand exhibits a strong effect so that the control potential of the NPF over time at least doubles with respect to its direct control (with the exception of 1996). One point we can learn from Table 1 is that the pyramid structure in which the NPF represents the state as the ultimate owner does not seem to add much to its direct ability to control. On the other hand, the instrument of the golden share is an important mechanism that enhances the control of the state considerably.

In Table 2 we present data in the same structure as in Table 1, but here the state is defined broadly and covers the NPF, other state agencies, and municipalities. The numbers in Table 2, panel A are in a sharp contrast to those presented in Table 1. The extent of state presence is greater and decreases at a much slower rate over time. More importantly, the number of firms that are under the direct control of the state steadily increases and the proportion of these firms in the sample reaches 56\% in 2005. Again (as in Table 1), control through the pyramid with a $50 \%$ voting right threshold enhances the control ability of the state only marginally. Again, the golden share drives considerable increases in control. In panel B we present the control potential for the $25 \%$ threshold, where the direct control in the early period is doubled when compared to the $50 \%$ benchmark, but declines somewhat towards the end of the research period. The 
importance of pyramidal control is only marginal throughout the period but the golden share enhances the control over about an additional $10 \%$ of firms. These findings are in line with evidence from both developed (Bortolotti and Faccio, 2006) as well as transformation (Chernykh, 2008) economies.

\subsection{State Control over Total Assets and Sales of Firms}

The numbers in Tables 1 and 2 do not reflect one important fact, which is the size of firms. By size we mean the importance of a company in terms of its ability to generate taxes and dividends, to provide employment and therefore tax income, and to provide economic opportunities for suppliers, which also provide employment and generate taxes. Hence, control over large companies creates a potential for achieving various economic and non-economic objectives. Indeed, the state has controlling voting rights in companies that differ by the size and extent of activities. In order to evaluate the extent of state control, taking the size and importance of the companies into account, we calculate the various degrees of state control using total assets and sales volumes. The total assets of a firm can be considered as a proxy for the size of each firm controlled by the state. Hence, it allows inferring the extent of state control over the large and important firms in the economy. Sales on other hand can be seen as an indication of the potential amount of taxes the state collects from controlled firms. These two proxies enable us to derive a perception of the economic power of the companies and consequently the extent of wealth that is controlled by the state through direct as well as pyramidal ownership channels.

For each extent of control we calculate separately the summary values of total assets under various degrees of state control. We begin with the sum under direct control based on majority voting rights. Specifically, $V_{t}^{D}=\sum_{j=1}^{N} A_{j t}[$ State $\geq 50 \%]$ defines the sum of the absolute values of the total assets of firms in year $t$ in which the state held more than a $50 \%$ share $\left(A_{j t}\right.$ is the accounting value of the total assets of firm $j$ where the state has such a direct stake in year $t$ ). Second, $V_{t}^{P}=\sum_{j=1}^{N} A_{j t}[$ Pyramid $\geq 50 \%]$ defines the sum of the absolute values of the total assets of the firms in year $t$ that were under integrated state control via a pyramid structure. Finally, we define a similar value for a 
structure that combines control via the pyramid and golden share together as $V_{t}^{P G}=\sum_{j=1}^{N} A_{j t}\{[$ Pyramid $\geq 50 \%] \wedge[$ GoldenShare $]\}$. The number of degrees of state control we consider (three) does not change over time but the number of firms where the state holds a controlling position differs from year to year. The overall value of these assets $V$ in a given year $t$ is the sum of the absolute values of the total assets of firms where a state position exists $\left(V_{t}=\sum_{j=1}^{N} V_{t}^{j}\right)$.

In terms of the volume of assets of firms where the state had voting rights a decreasing trend can bee seen in Tables 3 and 4. This pattern is paralleled in the evolution of assets over which the state as the NPF had majority voting rights (Table 3). Needless to say, the broadly-defined state manages to directly control a larger extent of those assets (Table 4). We see that the volumes of assets the state was able to control directly were decreasing over time from initially very high levels. The gradual decrease was at a slower rate in the case of the state defined broadly (Table 4) when compared to the position of the NPF (Table 3). An increase in controlled assets is evidenced only in 1996 for both voting thresholds; otherwise the extent of control remains on par with direct control. Increases in the property controlled through the pyramid and golden share are found to be more important, especially over the years 1997-2002. This finding hints at the preferences of the state to control the largest and most important firms directly rather than to engage in complicated schemes.

When we use the $25 \%$ threshold the general results are similar to those for the $50 \%$ one (Panel B in Tables 3 and 4). A specific feature to note is that the volumes of assets under state control are expectedly higher in the early years of the period under research but decrease to almost the same volumes as those measured with a $50 \%$ threshold of voting rights. In both threshold cases the decrease is gradual during the 1990's and rapid after 2000.

The pattern of control described above is very similar when we inspect the control potential over the extent of activity of the firms measured by sales. The values presented in Tables 5 and 6 are calculated in the same manner as those based on total assets. Again we see a stable decrease in the amount of sales over time as the number of firms where the state has voting rights drops as well (recall Tables 1 and 2). The direct control of the 
state over the volume of sales decreases as well. This decrease is much slower when compared to total assets (Tables 5 and 6) and especially in the case of the broadly defined state it is marginal (Table 6). One explanation may be the stable increases in the productivity of Czech firms because since 1998 inflation has been low and stable with a declining trend, being managed under an inflation targeting regime (Orlowski, 2008). The extent of the control increases quite considerably when a pyramid is complemented with the golden share in the earlier stages but such a control enhancement is less than marginal during 2004-2005. The patterns of control inferred from Tables 5 and 6 are the same for both voting right thresholds considered.

The extensive results on direct as well as integrated control of the state over the firms in the Czech Republic provides evidence that the state was primarily engaged in direct control. Arguably, the intention of the state to create special structures to effectively control firms and, hence, the economy was limited as opposed to empirical evidence from other transformation economies. Or an even more realistic explanation could be that the state was less than optimally organized and therefore did not exploit all means of control that, for example, a corporate pyramid offers. Surely, the integrated control of the state via a pyramid as well as its enhancement by the golden share was found to be less extensive than for example in Russia or China. These two large countries have run truly centralized economies, while centralization in the Czech Republic was less strict. These conditions might also be causes behind our findings as the Czech state bureaucracy apparently developed less efficient control enforcement than these two strictly centralized countries. Nevertheless, the control potential of the state remained substantial for a long period of time since we document that the state has been giving up its positions in firms only gradually and through a lengthy process.

\section{Effect of State Control on Corporate Performance}

In this section we complement our findings on the extent of state control by analyzing how various extents of state control affect the performance of controlled firms. In a similar manner as in the detailed studies of Hanousek, Kočenda and Svejnar (2007), Bortolotti and Faccio (2004), and Grosfeld and Tressel (2002), among others, we analyze the effects of specific levels of state control contrasted to several types of private owners. 
Our goal is to provide evidence of whether there is an effect of a specific level of state control on firms' performance and if so what is its magnitude.

In this respect we aim to perform an econometric analysis in the spirit of Angrist, Imbens, and Rubin (1996) and Angrist and Pischke (2009), whose approach we follow. Our model to be estimated is specified as a firm's performance being a function of ownership structures and some controls. Our specification, which exploits the intensively panel structure of our data and allows for fixed effects, bears the following form:

$$
\Delta \pi_{j t}=\alpha+\beta_{j} I O_{j}+\gamma_{j} \Delta T O_{j t}+\delta F_{j t}+\theta \operatorname{Ind}_{j t}+\varepsilon_{j t} .
$$

In the above specification index $j$ denotes firms and $t$ time periods. The dependent variable $\Delta \pi_{j t}$ is a measure of the corporate performance of firm $j$ during 1995-2005. The performance is calculated as an unweighted average over the sequence of periods 19951997, 1998-2000, 2001-2003, and 2004-2005. We use the period averages, calculated in the spirit of Kothari, Leone and Wasley (2005), in order to avoid potential fluctuations in data derived from the annual accounts of each firm. This is due to the fact that, for example, changes in bank loans and the total liabilities of firms might affect the values of performance indicators. Therefore, performance is measured as a difference in firm mean performance over a specific period with respect to the base period (1995-1997). We use two measures of performance: operating profit and sales; both measures are scaled by the firm's total assets. In line with the corporate finance literature we employ gross operating profit from which taxes are not yet subtracted. This allows a standard comparison of the performance of state-controlled and privately held firms. Both types of firms will attach a different priority on tax optimization because in the case of state-controlled firms, taxes will end up in the state budget anyway.

Further, variable $I O_{j t}$ measures the initial ownership structure of each firm $j$ in the base period following privatization that was officially concluded in February 1995. Variable $\Delta T O_{j t}$ measures the subsequent changes in the type of ownership structure of each firm $j$ in period $t$. Following our earlier exposition we distinguish direct and integrated control of the state as well as several types of private ownership (individual, industrial, and financial firms). Variable $F_{j t}$ controls for changes in the capital structure of each firm $j$ (total liabilities and bank loans scaled by total assets) that would not be eliminated by performance averages, and variable Ind controls for industrial sectors in 
which firm $j$ is categorized. Finally, constant $\alpha$ captures the remaining dispersed or unidentified ownership and $\varepsilon_{i t}$ is the error term. The above specification yields the marginal effects of specific types of owners and for our aim it delivers the effects of state control on corporate performance in percentages.

We present the estimates of the above specification in Tables 7-10. Tables 7 and 8 contain the results of the effects of ownership structure on performance measured by growth in operating profit scaled by total assets. In Table 7 the majority threshold of 50\% voting rights is used to define the benchmark of direct control, while the $25 \%$ threshold is applied in Table 8. In the upper part of each table we present the effects of various types of initial ownership that characterized each firm after its privatization. In the middle part we show how changes in ownership affected subsequent performance over time. For each period we show in separate columns the effects of the gradually increasing extent of state control from direct control by the NPF (columns marked C1) to fully integrated control: e.g. the broadly defined state (pyramid) having its control potential further enhanced by the golden share (columns marked C3). In the middle columns (C2) we report the effects of NPF direct control enhanced by a golden share. The effects of several types of private owners are reported for each period in the middle column as these ownership categories induce only marginal effects on coefficients related to the level of state control. In each column at the bottom of each table we also present the total number of observations of the performance indicator used in regressions, as well as the division of observations among the state-controlled or privately held firms.

The combined evidence from both tables is derived from an estimation in which we control for fixed effects and standard errors are heteroskedasticity consistent. Intertemporal changes in state control show a declining effect on operating profit, which even turns out to be negative for direct NPF control in the period that marked the end of the existence of this institution (2004-2005). Further, firms under the direct control of the broadly-defined state (C3) exhibit better results than firms under the control of the narrowly-defined state $(\mathrm{C} 1$ and $\mathrm{C} 2)$. From our data we infer that the decline has been driven by the negative results of firms belonging chiefly to the machinery sector.

Changes in ownership of industrial firms exhibit an increasing effect, albeit a moderate one when compared with the average influence of the state. This effect is also 
positive and larger for financial companies but only during the third period (2001-2003). This temporary effect may well be connected with the launch of the so-called Revitalization Program introduced by the government following the recession in 19981999 to aid firms in financial distress (for details see Lízal, 2002). Among other results stands out the effect of the initial ownership of industrial firms that during the periods from 2001-2005 shows an increasing positive effect. When put together with the previously-reported positive effect of changes in ownership by industrial firms, this finding points at a consolidation and restructuring process initiated by industrial firms after privatization. The time frame of these effects is in accord with the restructuring that was delayed and did not begin immediately after privatization but substantially advanced in the late 1990's (Hanousek and Kočenda, 2008). It is also evidence of the positive effect of foreign owners on performance because $94 \%$ of the industrial firms in our sample are foreign-held. The timing of the found effects coincides with the nearcompletion of restructuring.

In Tables 9 and 10 we present the results of the effects of ownership structure on performance measured by growth in sales scaled by total assets. The structure of both tables is the same as that of the two described earlier. The evidence in the form of statistically significant coefficients is more frequent than in the case of operating profit. A striking finding is the negative effect of state control in the form of initial ownership on firms' performance, which is deepening with time. This is also evidenced by coefficients related to changes in state ownership, as the state looses its grip. A potential reason for the worsening performance may lie in the state selling the best performing firms first. An alternative explanation of these patterns comes from the early post-privatization period when firms controlled by the NPF had better access to various tenders commissioned by the state, chiefly through informal networks and unofficial preferential access to tender conditions. These practices have been described by Lízal and Kočenda (2001) and criticized by Mlčoch (1998; p.952), who stressed that "the government should not meddle in a company's microeconomic choices". This environment enabled NPF-controlled firms to affect sales during the first period immediately following privatization, mainly through orders born from tenders. This was occurring without pressure on cost reduction, the feature that is in accord with our previous findings related to operating profit. 
In sharp contrast to the state ownership impact on performance, private initial ownership exhibits a positive effect that is steadily increasing for industrial firms but decreasing for individual owners. The effects of changes in these types of ownership are much less frequent but also positive. An exception is the negative effect of initial ownership by financial companies during the 1998-2000 period, complemented by the uniformly negative effects of changes of this specific type of ownership. This finding is in full accord with the results of Hanousek, Kočenda, and Svejnar (2007), who document a negative time-varying effect of the changes in ownership by investment funds and portfolio companies on sales already during the period 1996-1999. Reasons behind our findings may rest in lesser focus of financial firms on the core business of firms in which they hold stakes. This attitude is in contrast to the aim of industrial firms to increase profitability through cost cutting, integration of activities and expansion aimed at exploiting economies of scale.

We can summarize our findings to say that integrated state control does not yield superior performance. We document that the impact of various levels of state control resulted in declining and even negative corporate performance in firms where the state was engaged through various means of control. These results are the first evidence of the inferior effect of the corporate pyramid with the state at its apex. They also indirectly extend the findings of Hellman and Schankerman (2000), who showed that good state governance was not established across many transformation economies by 1999. Finally, the results are in sharp contrast to those found in other transformation economies where similar structures enabling effective state control emerged. However, usually these corporate structures were established by the state as a pragmatic tool to control the economy despite the economy's publicly proclaimed private nature (e.g. Chernykh, 2008; Ma, Yao and Xi, 2006; Bortolotti and Faccio, 2006; Liu and Sun, 2005).

\section{Concluding Remarks}

In this paper we analyze the extent of the integrated control of the state over privatized firms during the post-privatization decade (1995-2005) in the Czech Republic. During this period the integrated control potential of the state resembled a corporate pyramid, a business structure found worldwide. We find that the control potential that a corporate 
pyramid offers is not large when the Czech state is considered as the ultimate owner at the top of the pyramid. The state favored direct control provided by voting rights measured by a $50 \%$ threshold and such control increased when a less conservative $25 \%$ threshold was adopted. The use of the less conservative benchmark has been fully justified since no other subject with an exceeding extent of voting rights was detected at the same time. While pyramidal control was not fully utilized, the golden share in the hands of the state substantially enhanced its ability to control firms in terms of their numbers as well as in terms of the assets or sales they represent.

The state pyramid in the Czech Republic, to the extent of its existence, likely suffered from the dispersed nature of the state at the top of the pyramid where various state bodies could not efficiently interact to pursue the control. This is in opposite to, for example, institutional arrangements in China where state-owned business groups, when compared to government agencies, have direct rights to collect the economic income generated by their affiliated companies and also have greater incentives and capability to closely and effectively monitor managers of the group members (Ma, Yao and Xi, 2006).

We also analyze the effect of direct and integrated state ownership on corporate performance. We find that state control resulted in declining and even negative corporate performance in firms where the state was engaged through various means of control. Integrated state control was shown to be mostly inferior when compared with private types of ownership.

The numbers in our extensive data set provide hard evidence that the state indeed remained an important owner of privatized firms for a considerable period of time. Its reluctance to vacate its ownership positions is in striking contrast with the lack of capacity to push corporate performance in order to collect larger tax volumes. Lack of focus and inter-agency cooperation as well as the simple inefficiency of the state bureaucracy are the most likely reasons behind our findings. 


\section{References:}

Almeida, Heitor V. and Daniel Wolfenzon. 2006. Theory of Pyramidal Ownership and Family Business Groups. Journal of Finance 61(6), 2637-2680.

Aggarwal, Raj, and Joel T. Harper. 2000. Equity Valuation in the Czech Voucher Privatization Auctions, Financial Management, 29(4): 77-100.

Angrist, Joshua D., Guido W. Imbens, and Donald B. Rubin. 1996. "Identification of Causal Effects Using Instrumental Variables." Journal of the American Statistical Association 91 (434): 444-455.

Angrist, Joshua D. and Jörn-Steffen Pischke, 2009. Mostly Harmless Econometrics: An Empiricist's Companion. Princeton University Press.

Bebchuk, Lucian Arye, Reinier Kraakman, and George G. Triantis. 2000. "Stock Pyramids, Cross-Ownership, and Dual Class Equity: The Mechanisms and Agency Costs of Separating Control from Cash-Flow Rights." In Concentrated Corporate Ownership, ed. R. K. Morck. NBER Conference Report series. Chicago and London: University of Chicago Press, 295-315.

Bena, Hanousek, and Fons-Rosen (2009). Hidden or in a Plain View: Geography and Characteristics of European Pyramid Ownership Structures. CERGE-EI mimeo.

Bennett J, Estrin S, Maw J (2005) Why did transition economies choose mass privatization? Journal of European Economic Association, 3(2-3): 567-75

Berle, Adolf, and Gardiner Means. 1932. The Modern Corporation and Private Property. Vol. 1, chap. 5. New York: MacMillan.

Bortolotti, Bernardo and Faccio, Mara, 2004. Government Control of Privatized Firms. ECGI - Working Paper No. 40/2004. Available at SSRN: ssrn.com/abstract $=536683$

Bortolotti, Bernardo and Mara Faccio 2006. Reluctant privatization. Center for Economic Institutions Working paper series No. 2006-5.

Bureau Van Dijk, 2007. Bureau Van Dijk Electronic Publishing: Ownership Database. Available at www.bvdep.com. Accessed on March 5, 2009.

Chapelle, A. and A. Szafarz (2005), "Controlling firms through the majority voting rule", Physica A, 355, 509-529.

Chapelle, A. and A. Szafarz (2007), "Control consolidation with a threshold: An algorithm", IMA Journal of Management Mathematics, 18(3), 235-243. 
Chernykh, Lucy. 2008. Ultimate ownership and control in Russia. Journal of Financial Economics 88(1), 169-192.

Cull, Robert, Jana Matesova, and Mary Shirley. 2002. "Ownership and the Temptation to Loot: Evidence from Privatized Firms in the Czech Republic." Journal of Comparative Economics, 30(1): 1-24.

Estrin, S., Hanousek, J., Kočenda, E., Svejnar, J., 2009. Effects of Privatization and Ownership in Transition Economies. Journal of Economic Literature 47(3), 1-31.

Faccio, Mara, Larry H.P. Lang. 2002. The ultimate ownership of Western European Corporations. Journal of Financial Economics 65, 365-395

Frydman R, Gray C, Hessel M, Rapaczynski A (2000) The limits of discipline: ownership and hard budget constraints in the transition economies. Economics of Transition, 8(3): $577-601$

Frydman R, Hessel M, Rapaczynski A (2006) Why ownership matters? Entrepreneurship and the restructuring of enterprises in central Europe. In: Fox M, Heller M (ed) Corporate governance lessons from transition economies, Princeton University Press

Grosfeld, Irena and Tressel, Thierry, (2002). Competition and Ownership Structure: Substitutes or Complements? Evidence from the Warsaw Stock Exchange. Economics of Transition. 10 (3). 525-51.

Hanousek, J., and Kroch, E., 1998. The Two Waves of Voucher Privatization in the Czech Republic: A Model of Learning in Sequential Bidding, Applied Economics, 30: 133-143.

Hanousek, J., Kočenda, E., 2008. Potential of the State to Control Privatized Firms. Economic Change and Restructuring, 41(2), 167-186.

Hanousek, J., Kočenda, E., Svejnar, J., 2007. Origin and Concentration: Corporate Ownership, Control and Performance in Firms after Privatization. Economics of Transition, 15(1), 1-31.

Hellman, J., Jones, G., Kaufmann, D., 2003. Seize the state, seize the day: state capture and influence in transition economies. Journal of Comparative Economics, 31, 751-773.

Hellman J, Schankerman, M, 2000. Intervention, corruption and capture: The nexus between enterprises and the state. Economics of Transition 8(3): 545-576.

Johnson, Simon, Rafael La Porta, Florencio Lopez-de-Silanes, and Andrei Shleifer. 2000. “Tunneling." American Economic Review, 90(2): 22-27. 
Khanna, Tarun, Yishay Yafeh. 2007. Business Groups in Emerging Markets: Paragons or Parasites? Journal of Economic Literature 45, 331-372.

Kočenda, E., 1999. Residual State Property in the Czech Republic. Eastern European Economics, 37(5), 6-35.

Kothari, S.P., Andrew J. Leone, Charles E. Wasley, 2005. Performance matched discretionary accrual measures, Journal of Accounting and Economics, 39(1), 163-197.

Kotrba, J. and Svejnar, J. (1994). Rapid and Multifaceted Privatization: Experience of the Czech and Slovak Republics, Nomisma/Most, 4: 147-185.

La Porta, Rafael, Florencio Lopez-de-Silanes, and Andrei Shleifer, 1999, Corporate ownership around the world, Journal of Finance 54, 471-517.

Lízal, Lubomír. 2002. Determinants of Financial Distress: What Drives Bankruptcy in a Transition Economy? The Czech Republic Case. William Davidson Institute, Working Paper No. 451.

Lízal, L., Kočenda, E., 2001. State of Corruption in Transition: The Case of the Czech Republic. Emerging Markets Review, 2(2), 138-160.

Liu, Guy S. and Sun, Pei. 2005. The Class of Shareholdings and its Impacts on Corporate Performance: A Case of State Shareholding Composition in Chinese Public Corporations. Corporate Governance: An International Review, 13(1), 46-59.

Ma, X. and Lu, J., 2005.The critical role of business groups in China. Ivey Business Journal, 69(5), 1-12.

Ma, X., Yao, X., Xi, Y., 2006. Business group affiliation and firm performance in a transition economy: A focus on ownership voids. Asia Pacific Journal of Management, 23(4), 467-483.

Mlčoch, Lubomír. 1998. Czech Privatization: A Criticism of Misunderstood Liberalism (Keynote Address). Journal of Business Ethics, 17(9-10), 951-959.

Morck, Randall. 2009. The Riddle of the Great Pyramids. NBER Working Paper No. 14858 .

Morck, Randall, Daniel Wolfenzon, and Bernard Yeung, 2005, Corporate governance, economic entrenchment and growth, Journal of Economic Literature 43, 657-722.

Morck, Randall, David Stangeland, and Bernard Yeung. 2000. "Inherited Wealth, Corporate Control, and Economic Growth: The Canadian Disease," in Concentrated Corporate Ownership. Randall Morck, ed. Chicago: University of Chicago Press, 319-69. 
Morck, Randall, and Bernard Yeung. 2004. "Family Control and the Rent-Seeking Society." Entrepreneurship: Theory and Practice, 28(4): 391-409.

Orlowski, L., 2008. "Relative Inflation-Forecast as Monetary Policy Target for Convergence to the Euro", Journal of Policy Modeling. 30(6), 1061-1081.

Shleifer A, Vishny RW (1994) Politicians and firms. Quarterly Journal of Economics 109(4): 995-1025

Qian Y (1996).Enterprise reform in China: Agency problems and political control. Economics of Transition 4(2): 422-47

Yiu, D., Bruton, G., and Lu, Y. 2005. Understanding business group performance in an emerging economy: Acquiring resources and capabilities in order to prosper. Journal of Management Studies, 42(1): 183-296. 
Figure 1

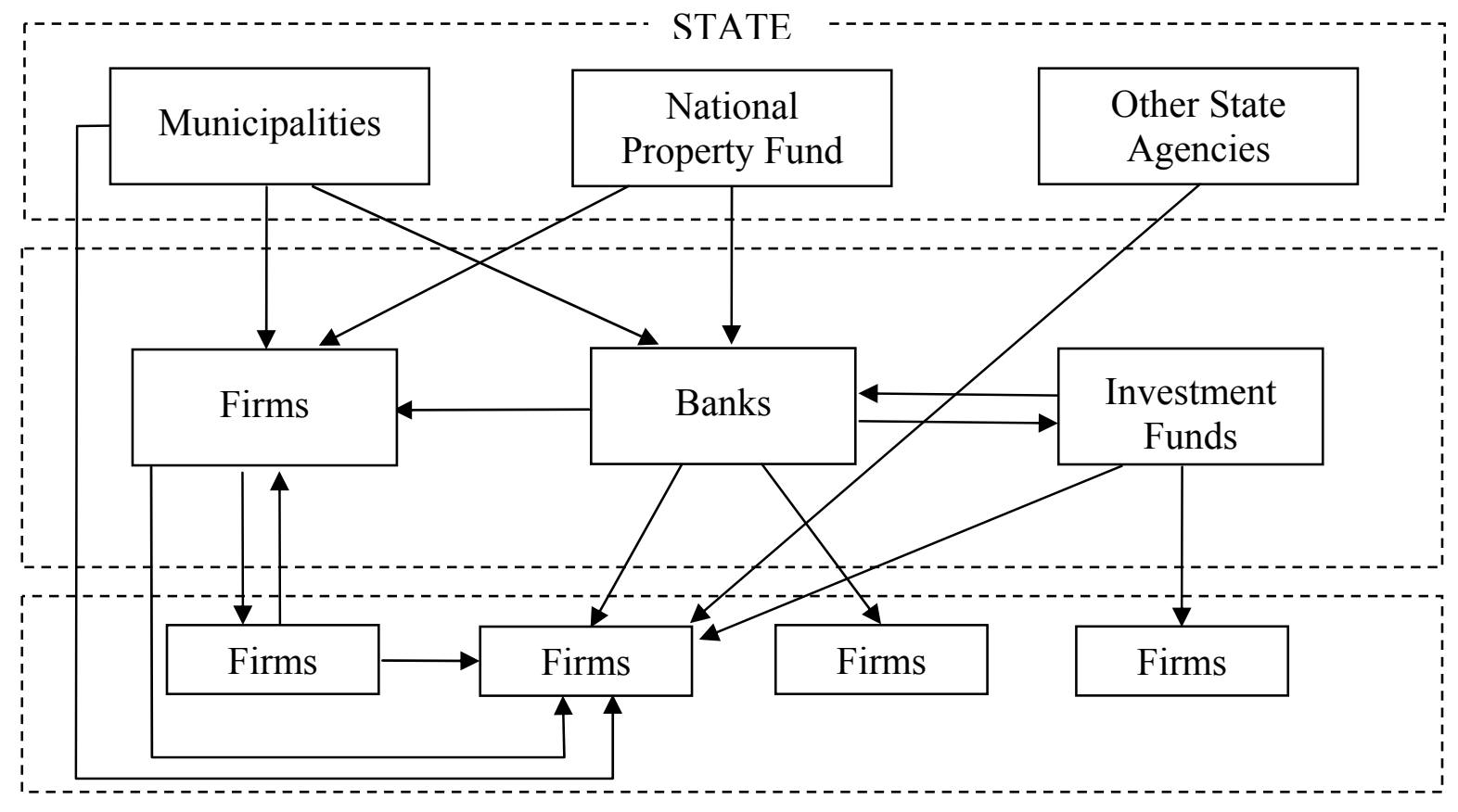


Table 1

State Control over Firms

(State Represented by the National Property Fund)

\begin{tabular}{|c|c|c|c|c|c|c|c|c|}
\hline \multicolumn{9}{|c|}{ Panel A: Majority Voting Rights of at least 50 percent } \\
\hline \multirow[b]{2}{*}{ Year } & \multirow{2}{*}{\multicolumn{2}{|c|}{ Total Number }} & \multicolumn{6}{|c|}{ Extent of the control } \\
\hline & & & \multicolumn{2}{|c|}{ Direct } & \multicolumn{2}{|c|}{ Pyramid } & \multicolumn{2}{|c|}{$\begin{array}{l}\text { Pyramid and } \\
\text { Golden Share }\end{array}$} \\
\hline 1996 & 814 & [ $100 \%]$ & 102 & {$[13 \%]$} & 103 & {$[13 \%]$} & NA & 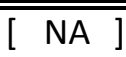 \\
\hline 1997 & & [ $100 \%$ ] & 70 & [ $15 \%$ ] & 70 & {$[15 \%]$} & 158 & [ $33 \%$ ] \\
\hline 1998 & 321 & [ $100 \%$ ] & 54 & [ $17 \%$ ] & 54 & [ $17 \%$ ] & 139 & [ 43\% ] \\
\hline 1999 & 269 & [ $100 \%$ ] & 53 & [ $20 \%$ ] & 53 & [ 20\% ] & 134 & {$[50 \%$ ] } \\
\hline 2000 & 241 & [ $100 \%$ ] & 52 & [ $22 \%$ ] & 52 & [ $22 \%$ ] & 130 & [ 54\% ] \\
\hline 2001 & 193 & [ $100 \%$ ] & 41 & [ 21\% ] & 42 & [ $22 \%$ ] & 94 & [ 49\% ] \\
\hline 2002 & 159 & [ $100 \%$ ] & 35 & [ 22\% ] & 35 & [ $22 \%$ ] & 73 & [ 46\% ] \\
\hline 2003 & 143 & [ 100\% ] & 30 & [ 21\% ] & 31 & [ 22\% ] & 63 & [ 44\% ] \\
\hline 2004 & 122 & [ $100 \%$ ] & 26 & [ 21\% ] & 26 & [ 21\% ] & 55 & [ 45\% ] \\
\hline 2005 & 104 & [ $100 \%$ ] & 25 & [ 24\% ] & 25 & [24\% ] & 54 & [ 52\% ] \\
\hline \multicolumn{9}{|c|}{ Panel B:. Voting Rights of at least 25 percent } \\
\hline \multirow[b]{2}{*}{ Year } & \multirow{2}{*}{\multicolumn{2}{|c|}{ Total Number }} & \multicolumn{6}{|c|}{ Extent of the control } \\
\hline & & & \multicolumn{2}{|c|}{ Direct } & \multicolumn{2}{|c|}{ Pyramid } & \multicolumn{2}{|c|}{$\begin{array}{l}\text { Pyramid and } \\
\text { Golden Share }\end{array}$} \\
\hline 1996 & 814 & [ $100 \%]$ & 210 & {$[26 \%]$} & 210 & {$[26 \%]$} & NA & {$\left[\begin{array}{l}\mathrm{NA}] \\
\end{array}\right.$} \\
\hline 1997 & 479 & [ $100 \%$ ] & 145 & [ $30 \%$ ] & 146 & [ $30 \%$ ] & 225 & [ $47 \%$ ] \\
\hline 1998 & 321 & [ $100 \%$ ] & 96 & [ $30 \%$ ] & 96 & [ $30 \%$ ] & 168 & [ $52 \%$ ] \\
\hline 1999 & 269 & [ $100 \%$ ] & 80 & [ $30 \%$ ] & 80 & [ $30 \%$ ] & 150 & [ $56 \%$ ] \\
\hline 2000 & 241 & [ $100 \%$ ] & 76 & [ $32 \%$ ] & 76 & [ 32\% ] & 146 & [ 61\% ] \\
\hline 2001 & 193 & [ $100 \%$ ] & 63 & [ $33 \%$ ] & 63 & [ 33\% ] & 107 & [ 55\% ] \\
\hline 2002 & 159 & [ $100 \%$ ] & 46 & [ 29\% ] & 46 & [ 29\% ] & 82 & [ 52\% ] \\
\hline 2003 & 143 & [ $100 \%$ ] & 37 & [ 26\% ] & 38 & [ 27\% ] & 73 & [ $51 \%$ ] \\
\hline 2004 & 122 & [ $100 \%$ ] & 31 & [ 25\% ] & 31 & [ 25\% ] & 62 & [ 51\% ] \\
\hline 2005 & 104 & [ $100 \%$ ] & 29 & [ $28 \%]$ & 29 & [ 28\% ] & 60 & [ 58\% ] \\
\hline
\end{tabular}

Note: Total Number denotes number of firms where state has any voting rights. Direct defines control through 50 and $25 \%$ voting rights respectively. Numbers in brackets denote percentages with respect to the base that is Total Number in respective year.

Pyramid defines control through chain of successive voting rights of 50 and $25 \%$ respectively. Golden Share defines control through this instrument. 
Table 2

State Control over Firms

(State Defined Broadly: NPF, Municipalities, and State Agencies)

\begin{tabular}{|c|c|c|c|c|c|c|c|c|}
\hline \multicolumn{9}{|c|}{ Panel A: Majority Voting Rights of at least 50 percent } \\
\hline \multirow[b]{2}{*}{ Year } & \multirow{2}{*}{\multicolumn{2}{|c|}{ Total Number }} & \multicolumn{6}{|c|}{ Extent of the control } \\
\hline & & & \multicolumn{2}{|c|}{ Direct } & \multicolumn{2}{|c|}{ Pyramid } & \multicolumn{2}{|c|}{$\begin{array}{l}\text { Pyramid and } \\
\text { Golden Share }\end{array}$} \\
\hline 1996 & 889 & {$[100 \%]$} & 133 & {$[15 \%]$} & 136 & {$[15 \%]$} & NA & {$\left[\begin{array}{lll}\text { NA ] } \\
\end{array}\right.$} \\
\hline 1997 & 570 & [ $100 \%$ ] & 122 & [ $21 \%$ ] & 125 & [ 22\% ] & 213 & [ $37 \%$ ] \\
\hline 1998 & 436 & [ $100 \%$ ] & 128 & [ 29\% ] & 131 & [ $30 \%$ ] & 217 & [ $50 \%$ ] \\
\hline 1999 & 406 & [ $100 \%$ ] & 143 & [ $35 \%$ ] & 147 & [ $36 \%$ ] & 228 & [ 56\% ] \\
\hline 2000 & 413 & [ $100 \%$ ] & 163 & [ 39\% ] & 166 & [ 40\% ] & 244 & [ 59\% ] \\
\hline 2001 & 411 & [ $100 \%$ ] & 180 & [ 44\% ] & 184 & [ 45\% ] & 237 & [ 58\% ] \\
\hline 2002 & 404 & [ $100 \%$ ] & 194 & [ 48\% ] & 197 & [ 49\% ] & 236 & [ 58\% ] \\
\hline 2003 & 417 & [ $100 \%$ ] & 206 & [ 49\% ] & 209 & [ 50\% ] & 241 & [ 58\% ] \\
\hline 2004 & & [ $100 \%$ ] & 215 & [ 52\% ] & 218 & [ 53\% ] & 245 & [ $60 \%$ ] \\
\hline 2005 & 394 & [ $100 \%$ ] & 221 & [ 56\% ] & 224 & [ $57 \%$ ] & 253 & [ 64\% ] \\
\hline \multicolumn{9}{|c|}{ Panel B:. Voting Rights of at least 25 percent } \\
\hline \multirow[b]{2}{*}{ Year } & \multirow{2}{*}{\multicolumn{2}{|c|}{ Total Number }} & \multicolumn{6}{|c|}{ Extent of the control } \\
\hline & & & \multicolumn{2}{|c|}{ Direct } & \multicolumn{2}{|c|}{ Pyramid } & \multicolumn{2}{|c|}{$\begin{array}{l}\text { Pyramid and } \\
\text { Golden Share }\end{array}$} \\
\hline 1996 & 889 & {$[100 \%]$} & 262 & [ 29\% ] & 262 & {$[29 \%]$} & NA & [ NA ] \\
\hline 1997 & 570 & [ $100 \%$ ] & 213 & [ $37 \%$ ] & 214 & [ $38 \%$ ] & 296 & [ $52 \%$ ] \\
\hline 1998 & 436 & [ $100 \%$ ] & 188 & [ $43 \%$ ] & 188 & [ 43\% ] & 262 & [ $60 \%$ ] \\
\hline 1999 & 406 & [ $100 \%$ ] & 191 & [ $47 \%$ ] & 191 & [ 47\% ] & 262 & [ $65 \%$ ] \\
\hline 2000 & 413 & [ $100 \%$ ] & 214 & [ $52 \%$ ] & 215 & [ 52\% ] & 282 & [ 68\% ] \\
\hline 2001 & 411 & [ $100 \%$ ] & 236 & [ 57\% ] & 237 & [ 58\% ] & 279 & [ 68\% ] \\
\hline 2002 & 404 & [ $100 \%$ ] & 240 & [ 59\% ] & 242 & [ 60\% ] & 276 & [ 68\% ] \\
\hline 2003 & 417 & [ $100 \%$ ] & 251 & [ 60\% ] & 254 & [ 61\% ] & 288 & [ 69\% ] \\
\hline 2004 & 411 & [ $100 \%$ ] & 260 & [ 63\% ] & 262 & [ 64\% ] & 291 & [ 71\% ] \\
\hline 2005 & 394 & [ $100 \%$ ] & 260 & [ 66\% ] & 263 & [ 67\% ] & 293 & [ 74\% ] \\
\hline
\end{tabular}

Note: Total Number denotes number of firms where state has any voting rights. Direct defines control through 50 and $25 \%$ voting rights respectively. Numbers in brackets denote percentages with respect to the base that is Total Number in respective year.

Pyramid defines control through chain of successive voting rights of 50 and $25 \%$ respectively. Golden Share defines control through this instrument. 
Table 3

State Control over Total Assets of Firms

(State Represented by the National Property Fund)

\begin{tabular}{|c|c|c|c|c|c|c|c|c|}
\hline \multicolumn{9}{|c|}{ Panel A. Control using simple majority (50 percent) rule } \\
\hline \multirow[b]{2}{*}{ Year } & \multicolumn{8}{|c|}{ Extent of the control } \\
\hline & \multicolumn{2}{|c|}{ State Present } & \multicolumn{2}{|c|}{ Direct } & \multicolumn{2}{|c|}{ Pyramid } & \multicolumn{2}{|c|}{$\begin{array}{l}\text { Pyramid and } \\
\text { Golden Share }\end{array}$} \\
\hline 1996 & 2310 & [ $75 \%]$ & 888 & [ 29\% ] & 895 & [ 29\% ] & NA & [ NA \\
\hline 1997 & 2230 & [ $74 \%$ ] & 446 & [ $15 \%$ ] & 446 & [ $15 \%$ ] & 830 & [ $28 \%$ \\
\hline 1998 & 1850 & [ $63 \%]$ & 455 & [ $16 \%$ ] & 455 & [ $16 \%$ ] & 624 & [ $21 \%$ \\
\hline 1999 & 1780 & [ $48 \%$ ] & 855 & [ $23 \%]$ & 855 & [ $23 \%]$ & 1020 & [ $27 \%$ \\
\hline 2000 & 1410 & [ $33 \%]$ & 966 & {$[23 \%]$} & 966 & [ $23 \%]$ & 1140 & [ $27 \%$ \\
\hline 2001 & 837 & [ $18 \%$ ] & 520 & [ 11\% ] & 533 & [ $12 \%$ ] & 676 & [ $15 \%$ \\
\hline 2002 & 768 & [ $18 \%]$ & 494 & [ $12 \%]$ & 494 & [ $12 \%]$ & 607 & {$[14 \%]$} \\
\hline 2003 & 638 & [ $13 \%]$ & 438 & [ $9 \%]$ & 439 & {$\left[\begin{array}{ll}9 \% & \end{array}\right]$} & 484 & {$[10 \%]$} \\
\hline 2004 & 552 & [ $10 \%$ ] & 439 & [ $8 \%$ ] & 439 & {$\left[\begin{array}{ll}8 \% & 8\end{array}\right]$} & 469 & [ 9\% \\
\hline 2005 & 504 & {$\left[\begin{array}{ll}7 \% & ]\end{array}\right.$} & 395 & $5 \%$ ] & 395 & $5 \%]$ & 426 & $6 \%$ \\
\hline \multicolumn{9}{|c|}{ Panel B. Control using 25 percent rule } \\
\hline \multirow[b]{2}{*}{ Year } & \multicolumn{8}{|c|}{ Extent of the control } \\
\hline & \multicolumn{2}{|c|}{ State Present } & \multicolumn{2}{|c|}{ Direct } & \multicolumn{2}{|c|}{ Pyramid } & \multicolumn{2}{|c|}{$\begin{array}{l}\text { Pyramid and } \\
\text { Golden Share }\end{array}$} \\
\hline 1996 & 2310 & [ 75\% ] & 1440 & [ $47 \%$ ] & 1460 & [ $47 \%$ ] & & $\begin{array}{ll}\text { NA } \\
\end{array}$ \\
\hline 1997 & 2230 & [ $74 \%]$ & 1910 & [ 63\% ] & 1910 & [ $63 \%]$ & 1960 & {$[65 \%$ ] } \\
\hline 1998 & 1850 & [ $63 \%$ ] & 1650 & [ $57 \%$ ] & 1650 & [ $57 \%$ ] & 1710 & [ 59\% ] \\
\hline 1999 & 1780 & [ $48 \%$ ] & 1460 & [ 39\% ] & 1460 & [ $39 \%$ ] & 1660 & {$[45 \%$ ] } \\
\hline 2000 & 1410 & [ $33 \%$ ] & 1090 & [ 26\% ] & 1090 & [ 26\% ] & 1330 & {$[31 \%]$} \\
\hline 2001 & 837 & [ $18 \%$ ] & 721 & [ $16 \%$ ] & 721 & [ $16 \%]$ & 782 & {$[17 \%$ ] } \\
\hline 2002 & 768 & [ $18 \%$ ] & 565 & [ $13 \%$ ] & 565 & {$[13 \%]$} & 670 & {$[16 \%$ ] } \\
\hline 2003 & 638 & [ $13 \%$ ] & 453 & [ $9 \%$ ] & 454 & {$\left[\begin{array}{lll} & 9 \%\end{array}\right]$} & 552 & [ $11 \%$ ] \\
\hline 2004 & 552 & [ $10 \%]$ & 440 & [ $8 \%$ ] & 440 & {$\left[\begin{array}{ll}8 \% & ]\end{array}\right.$} & 471 & {$\left[\begin{array}{ll}9 \% & ]\end{array}\right.$} \\
\hline 2005 & 504 & {$\left[\begin{array}{ll}7 \% & ]\end{array}\right.$} & 396 & $5 \%]$ & 396 & $5 \% \quad]$ & 427 & $6 \%$ \\
\hline
\end{tabular}

Note: Total Number denotes number of firms where state has any voting rights. Direct defines control through 50 and $25 \%$ voting rights respectively.

Numbers in brackets denote percentages with respect to the base that is Total Number in respective year.

Pyramid defines control through chain of successive voting rights of 50 and $25 \%$ respectively. Golden Share defines control through this instrument. 
Table 4

State Control over Total Assets of Firms

(State Defined Broadly: NPF, Municipalities, and State Agencies)

\begin{tabular}{|c|c|c|c|c|c|c|c|c|}
\hline \multicolumn{9}{|c|}{ Panel A. Control using simple majority (50 percent) rule } \\
\hline \multirow[b]{2}{*}{ Year } & \multicolumn{8}{|c|}{ Extent of the control } \\
\hline & \multicolumn{2}{|c|}{ State Present } & \multicolumn{2}{|c|}{ Direct } & \multicolumn{2}{|c|}{ Pyramid } & \multicolumn{2}{|c|}{$\begin{array}{l}\text { Pyramid and } \\
\text { Golden Share }\end{array}$} \\
\hline 1996 & 2430 & [ 79\% ] & 1000 & [ $32 \%]$ & 1010 & [ $33 \%]$ & NA & [ NA \\
\hline 1997 & 2350 & [ $78 \%$ ] & 563 & [ $19 \%$ ] & 563 & [ $19 \%$ ] & 946 & [ $31 \%$ \\
\hline 1998 & 2020 & [ 69\% ] & 618 & [ $21 \%$ ] & 620 & [ $21 \%$ ] & 789 & {$[27 \%$ ] } \\
\hline 1999 & 1980 & [ 53\% ] & 1040 & [ $28 \%$ ] & 1040 & [ $28 \%$ ] & 1200 & {$[32 \%$ ] } \\
\hline 2000 & 1680 & [ $40 \%$ ] & 1210 & [ 29\% ] & 1210 & [ $29 \%$ ] & 1380 & [ $33 \%$ ] \\
\hline 2001 & 1130 & [ $24 \%$ ] & 778 & [ $17 \%$ ] & 792 & [ $17 \%$ ] & 935 & [ 20\% ] \\
\hline 2002 & 1090 & [ $26 \%$ ] & 741 & {$[18 \%]$} & 743 & [ $18 \%$ ] & 855 & [ 20\% ] \\
\hline 2003 & 1020 & [ $20 \%$ ] & 732 & [ $15 \%]$ & 735 & [ $15 \%]$ & 777 & [ $16 \%$ ] \\
\hline 2004 & 929 & [ $17 \%$ ] & 735 & [ $14 \%$ ] & 737 & [ $14 \%$ ] & 763 & [ $14 \%$ ] \\
\hline 2005 & 935 & [ $12 \%$ ] & 784 & [ $10 \%]$ & 785 & {$[10 \%]$} & 812 & {$[11 \%$} \\
\hline \multicolumn{9}{|c|}{ Panel B. Control using 25 percent rule } \\
\hline \multirow[b]{2}{*}{ Year } & \multicolumn{8}{|c|}{ Extent of the control } \\
\hline & \multicolumn{2}{|c|}{ State Present } & \multicolumn{2}{|c|}{ Direct } & \multicolumn{2}{|c|}{ Pyramid } & \multicolumn{2}{|c|}{$\begin{array}{l}\text { Pyramid and } \\
\text { Golden Share }\end{array}$} \\
\hline 1996 & 2430 & {$[79 \%]$} & 1570 & {$[51 \%]$} & 1580 & {$[51 \%]$} & NA & [ [NA ] \\
\hline 1997 & 2350 & [ $78 \%$ ] & 2030 & {$[67 \%$ ] } & 2030 & {$[67 \%$ ] } & 2080 & [ $69 \%$ ] \\
\hline 1998 & 2020 & [ $69 \%$ ] & 1820 & {$[62 \%]$} & 1820 & {$[62 \%]$} & 1880 & [ $64 \%$ ] \\
\hline 1999 & 1980 & [ $53 \%$ ] & 1650 & [ $44 \%$ ] & 1650 & [ $44 \%$ ] & 1850 & [ $50 \%$ ] \\
\hline 2000 & 1680 & [ $40 \%$ ] & 1350 & {$[32 \%]$} & 1350 & {$[32 \%]$} & 1590 & [ $38 \%$ ] \\
\hline 2001 & 1130 & [ $24 \%$ ] & 998 & [ $22 \%$ ] & 998 & [ $22 \%$ ] & 1060 & [ $23 \%$ ] \\
\hline 2002 & 1090 & [ $26 \%$ ] & 836 & [ $20 \%$ ] & 836 & {$[20 \%]$} & 940 & {$[22 \%]$} \\
\hline 2003 & 1020 & [ $20 \%$ ] & 771 & {$[15 \%]$} & 772 & [ $15 \%$ ] & 869 & [ $17 \%$ ] \\
\hline 2004 & 929 & [ $17 \%$ ] & 760 & [ $14 \%$ ] & 760 & [ $14 \%$ ] & 788 & [ $15 \%$ ] \\
\hline 2005 & 935 & [ $12 \%$ ] & 802 & [ $11 \%]$ & 802 & {$[11 \%]$} & 828 & [ $11 \%$ ] \\
\hline
\end{tabular}

Note: Total Number denotes number of firms where state has any voting rights. Direct defines control through 50 and $25 \%$ voting rights respectively.

Numbers in brackets denote percentages with respect to the base that is Total Number in respective year.

Pyramid defines control through chain of successive voting rights of 50 and $25 \%$ respectively. Golden Share defines control through this instrument. 
Table 5

State Control over Sales Produced by Firms

(State Represented by the National Property Fund)

\begin{tabular}{|c|c|c|c|c|c|c|c|c|c|}
\hline \multicolumn{10}{|c|}{ Panel A. Control using simple majority (50 percent) rule } \\
\hline \multirow[b]{2}{*}{ Year } & \multicolumn{9}{|c|}{ Extent of the control } \\
\hline & \multicolumn{2}{|c|}{ State Present } & \multicolumn{3}{|c|}{ Direct } & \multicolumn{2}{|c|}{ Pyramid } & \multicolumn{2}{|c|}{$\begin{array}{l}\text { Pyramid and } \\
\text { Golden Share }\end{array}$} \\
\hline 1996 & 803 & [ $26 \%]$ & 248 & [ & $8 \%]$ & 248 & {$\left[\begin{array}{ll}8 \% & ]\end{array}\right.$} & NA & [ NA \\
\hline 1997 & 681 & [ $23 \%]$ & 188 & [ & $6 \%]$ & 188 & {$\left[\begin{array}{ll}6 \% & ]\end{array}\right]$} & 334 & {$[11 \%$} \\
\hline 1998 & 588 & [ $20 \%]$ & 184 & 1 & $6 \%]$ & 184 & {$\left[\begin{array}{ll}6 \% & ]\end{array}\right]$} & 314 & [ $11 \%$ \\
\hline 1999 & 512 & [ $14 \%$ ] & 221 & [ & $6 \%$ ] & 221 & {$\left[\begin{array}{ll}6 \% & 6 \%\end{array}\right]$} & 340 & [ 9\% \\
\hline 2000 & 467 & [ $11 \%$ ] & 234 & [ & $6 \%]$ & 234 & {$\left[\begin{array}{ll}6 \% & 6\end{array}\right]$} & 360 & [ $9 \%$ \\
\hline 2001 & 476 & [ $10 \%]$ & 267 & [ & $6 \%$ ] & 277 & {$\left[\begin{array}{ll}6 \% & ]\end{array}\right.$} & 377 & [ $8 \%$ \\
\hline 2002 & 414 & [ $10 \%$ ] & 214 & [ & $5 \%]$ & 214 & {$\left[\begin{array}{ll}5 \% & 5 \%\end{array}\right]$} & 287 & [ $7 \%$ \\
\hline 2003 & 252 & {$\left[\begin{array}{ll}5 \% & ]\end{array}\right.$} & 160 & [ & $3 \%$ ] & 160 & {$\left[\begin{array}{ll}3 \% & 3 \%\end{array}\right.$} & 175 & [ $4 \%$ \\
\hline 2004 & 224 & {$\left[\begin{array}{lll} & 4 \%\end{array}\right]$} & 173 & [ & $3 \%$ ] & 173 & {$\left[\begin{array}{lll}{[} & 3 \% & ]\end{array}\right]$} & 178 & [ $3 \%$ \\
\hline 2005 & 167 & [ $2 \%$ ] & 124 & [ & $2 \%]$ & 124 & {$\left[\begin{array}{lll} & 2 \% & ]\end{array}\right.$} & 129 & [ $2 \%$ \\
\hline \multicolumn{10}{|c|}{ Panel B. Control using 25 percent rule } \\
\hline \multirow[b]{2}{*}{ Year } & \multicolumn{9}{|c|}{ Extent of the control } \\
\hline & \multicolumn{2}{|c|}{ State Present } & \multicolumn{3}{|c|}{ Direct } & \multicolumn{2}{|c|}{ Pyramid } & \multicolumn{2}{|c|}{$\begin{array}{l}\text { Pyramid and } \\
\text { Golden Share }\end{array}$} \\
\hline 1996 & 803 & {$[26 \%]$} & 452 & & $15 \%]$ & 463 & {$[15 \%]$} & NA & [NA ] \\
\hline 1997 & 681 & [ $23 \%$ ] & 499 & & $17 \%$ ] & 501 & {$[17 \%]$} & 529 & [ $18 \%$ ] \\
\hline 1998 & 588 & [ $20 \%$ ] & 471 & & $16 \%$ ] & 472 & {$[16 \%]$} & 501 & [ $17 \%$ ] \\
\hline 1999 & 512 & [ $14 \%$ ] & 373 & & $10 \%]$ & 373 & {$[10 \%]$} & 443 & [ $12 \%$ ] \\
\hline 2000 & 467 & [ $11 \%$ ] & 323 & & $8 \%$ ] & 323 & {$\left[\begin{array}{ll}8 \% & 8 \%\end{array}\right]$} & 422 & [ $10 \%$ ] \\
\hline 2001 & 476 & [ $10 \%$ ] & 410 & 1 & $9 \%$ ] & 410 & {$\left[\begin{array}{ll}9 \% & 9 \%\end{array}\right.$} & 441 & [ $10 \%$ ] \\
\hline 2002 & 414 & [ $10 \%$ ] & 269 & & $6 \%$ ] & 269 & {$\left[\begin{array}{lll} & 6 \% & ]\end{array}\right]$} & 317 & {$\left[\begin{array}{ll}8 \% & ]\end{array}\right.$} \\
\hline 2003 & 252 & {$\left[\begin{array}{ll}5 \% & \text { ] }\end{array}\right.$} & 166 & & $3 \%$ ] & 166 & {$\left[\begin{array}{lll} & 3 \% & ]\end{array}\right]$} & 204 & [ $4 \%$ \\
\hline 2004 & 224 & {$\left[\begin{array}{ll}4 \% & \end{array}\right]$} & 173 & & $3 \%$ ] & 173 & {$\left[\begin{array}{ll}3 \% & 3 \%\end{array}\right]$} & 180 & [ $3 \%$ \\
\hline 2005 & 167 & {$\left[\begin{array}{ll}2 \% & 2 \%\end{array}\right.$} & 124 & [ & $2 \%]$ & 124 & {$\left[\begin{array}{ll}2 \% & 2 \%\end{array}\right]$} & 129 & {$\left[\begin{array}{ll}2 \% & 2 \%\end{array}\right.$} \\
\hline
\end{tabular}

Note: Total Number denotes number of firms where state has any voting rights. Direct defines control through 50 and $25 \%$ voting rights respectively.

Numbers in brackets denote percentages with respect to the base that is Total Number in respective year.

Pyramid defines control through chain of successive voting rights of 50 and $25 \%$ respectively. Golden Share defines control through this instrument. 
Table 6

State Control over Sales Produced by Firms

(State Defined Broadly: NPF, Municipalities, and State Agencies)

\begin{tabular}{|c|c|c|c|c|c|c|c|c|}
\hline \multicolumn{9}{|c|}{ Panel A. Control using simple majority (50 percent) rule } \\
\hline \multirow{3}{*}{$\begin{array}{l}\text { Year } \\
1996\end{array}$} & \multicolumn{8}{|c|}{ Extent of the control } \\
\hline & \multicolumn{2}{|c|}{ State Present } & \multicolumn{2}{|c|}{ Direct } & \multicolumn{2}{|c|}{ Pyramid } & \multicolumn{2}{|c|}{$\begin{array}{l}\text { Pyramid and } \\
\text { Golden Share }\end{array}$} \\
\hline & 840 & {$[27 \%]$} & 271 & [9\%] & 271 & $9 \%]$ & NA & [ NA \\
\hline 1997 & 713 & [ $24 \%]$ & 210 & [ $7 \%]$ & 210 & $7 \% \quad]$ & 357 & [ $12 \%$ \\
\hline 1998 & 667 & [ $23 \%]$ & 254 & $9 \%]$ & 254 & $9 \% \quad]$ & 385 & [ $13 \%$ \\
\hline 1999 & 591 & [ $16 \%$ ] & 291 & $8 \%]$ & 291 & $8 \% \quad]$ & 410 & [ $11 \%$ \\
\hline 2000 & 560 & [ $13 \%$ ] & 310 & {$\left[\begin{array}{l}7 \% \\
{[}\end{array}\right.$} & 310 & $7 \% \quad]$ & 435 & [ $10 \%$ \\
\hline 2001 & 575 & [ $12 \%$ ] & 342 & {$[7 \%]$} & 352 & $8 \% \quad]$ & 452 & [ $10 \%$ \\
\hline 2002 & 519 & [ $12 \%$ ] & 278 & $7 \%]$ & 278 & $7 \% \quad]$ & 351 & [ $8 \%$ \\
\hline 2003 & 419 & {$\left[\begin{array}{ll}8 \% & \text { ] }\end{array}\right.$} & 259 & $5 \%]$ & 260 & $5 \% \quad]$ & 275 & [ $6 \%$ \\
\hline 2004 & 392 & {$\left[\begin{array}{ll}7 \% & \text { ] }\end{array}\right.$} & 273 & $5 \%]$ & 274 & $5 \%]$ & 278 & [ $5 \%$ \\
\hline 2005 & 316 & [ $4 \%$ ] & 234 & $3 \%]$ & 234 & $3 \% \quad]$ & 239 & $3 \%$ \\
\hline \multicolumn{9}{|c|}{ Panel B. Control using 25 percent rule } \\
\hline \multirow[b]{2}{*}{ Year } & \multicolumn{8}{|c|}{ Extent of the control } \\
\hline & \multicolumn{2}{|c|}{ State Present } & \multicolumn{2}{|c|}{ Direct } & \multicolumn{2}{|c|}{ Pyramid } & \multicolumn{2}{|c|}{$\begin{array}{l}\text { Pyramid and } \\
\text { Golden Share }\end{array}$} \\
\hline 1996 & 840 & [ 27\% ] & 476 & {$[15 \%]$} & 487 & $16 \%]$ & NA & [NA \\
\hline 1997 & 713 & [ $24 \%$ ] & 524 & {$[17 \%]$} & 525 & $17 \%]$ & 554 & [ $18 \%$ \\
\hline 1998 & 667 & [ $23 \%$ ] & 543 & [ $19 \%]$ & 545 & $19 \%]$ & 574 & [ $20 \%$ \\
\hline 1999 & 591 & [ $16 \%$ ] & 446 & {$[12 \%]$} & 446 & $12 \%]$ & 516 & [ $14 \%$ \\
\hline 2000 & 560 & [ $13 \%]$ & 403 & [ $10 \%]$ & 403 & $10 \%]$ & 503 & [ $12 \%$ \\
\hline 2001 & 575 & [ $12 \%$ ] & 492 & [ $11 \%$ ] & 492 & $11 \%]$ & 523 & [ $11 \%$ \\
\hline 2002 & 519 & [ $12 \%$ ] & 340 & [ $8 \%]$ & 341 & $8 \% \quad]$ & 389 & [ $9 \%$ \\
\hline 2003 & 419 & {$\left[\begin{array}{ll}8 \% & \text { ] }\end{array}\right.$} & 273 & $5 \%]$ & 273 & $5 \% \quad]$ & 313 & [ $6 \%$ \\
\hline 2004 & 392 & {$\left[\begin{array}{ll}7 \% & ]\end{array}\right.$} & 283 & $5 \%]$ & 284 & $5 \%]$ & 291 & [ $5 \%$ \\
\hline 2005 & 316 & [ $4 \%$ ] & 239 & [ $3 \%]$ & 240 & $3 \% \quad]$ & 246 & [ $3 \%$ \\
\hline
\end{tabular}

Note: Total Number denotes number of firms where state has any voting rights. Direct defines control through 50 and $25 \%$ voting rights respectively.

Numbers in brackets denote percentages with respect to the base that is Total Number in respective year.

Pyramid defines control through chain of successive voting rights of 50 and $25 \%$ respectively. Golden Share defines control through this instrument. 
Table 7. Performance: Operating profit/total assets (50\% control)

\begin{tabular}{|c|c|c|c|c|c|c|c|c|c|}
\hline \multirow{2}{*}{ Variable } & \multicolumn{3}{|c|}{$1998-2000$} & \multicolumn{3}{|c|}{ 2001-2003 } & \multicolumn{3}{|c|}{$2004-2005$} \\
\hline & C1 & $\mathrm{C} 2$ & $\mathrm{C} 3$ & C1 & $\mathrm{C} 2$ & $\mathrm{C3}$ & C1 & $\mathrm{C} 2$ & $\mathrm{C} 3$ \\
\hline \multicolumn{10}{|c|}{ Initial post privatization ownership } \\
\hline State & $\begin{array}{l}-0.006 \\
(0.026)\end{array}$ & $\begin{array}{l}0.008 \\
(0.015)\end{array}$ & $\begin{array}{l}0.003 \\
(0.015)\end{array}$ & $\begin{array}{l}-0.113 \\
(0.092)\end{array}$ & $\begin{array}{l}-0.004 \\
(0.020)\end{array}$ & $\begin{array}{l}-0.034 \\
(0.025)\end{array}$ & $\begin{array}{l}0.150 \\
(0.289)\end{array}$ & $\begin{array}{l}0.019 \\
(0.012)\end{array}$ & $\begin{array}{l}0.011 \\
(0.014)\end{array}$ \\
\hline Financial Co. & & $\begin{array}{l}-0.044 \\
(0.029)\end{array}$ & & & $\begin{array}{l}-0.058 \\
(0.090)\end{array}$ & & & $\begin{array}{l}0.089 \\
(0.193)\end{array}$ & \\
\hline Big industrial Co. & & $\begin{array}{l}-0.020 \\
(0.018)\end{array}$ & & & $\begin{array}{l}0.040^{*} \\
(0.021)\end{array}$ & & & $\begin{array}{l}0.223^{*} \\
(0.123)\end{array}$ & \\
\hline Individual Owner & & $\begin{array}{l}-0.049 * * \\
(0.018)\end{array}$ & & & $\begin{array}{l}0.044 \\
(0.079)\end{array}$ & & & $\begin{array}{l}-0.504 \\
(0.551)\end{array}$ & \\
\hline \multicolumn{10}{|c|}{ Subsequent changes in ownership (w.r. to the first period: 1995-1997) } \\
\hline State & $\begin{array}{l}0.108^{*} \\
(0.061)\end{array}$ & $\begin{array}{l}0.134 * * \\
(0.055)\end{array}$ & $\begin{array}{l}0.114^{* *} \\
(0.050)\end{array}$ & $\begin{array}{l}0.048 \\
(0.058)\end{array}$ & $\begin{array}{l}0.018 \\
(0.027)\end{array}$ & $\begin{array}{l}-0.012 \\
(0.029)\end{array}$ & $\begin{array}{l}-0.055 \\
(0.044)\end{array}$ & $\begin{array}{l}0.003 \\
(0.026)\end{array}$ & $\begin{array}{l}-0.008 \\
(0.021)\end{array}$ \\
\hline Financial Co. & & $\begin{array}{l}-0.037 \\
(0.035)\end{array}$ & & & $\begin{array}{l}0.158 * * \\
(0.080)\end{array}$ & & & $\begin{array}{l}-0.008 \\
(0.027)\end{array}$ & \\
\hline Big industrial Co. & & $\begin{array}{l}-0.021 \\
(0.014)\end{array}$ & & & $\begin{array}{l}0.011 * * \\
(0.005)\end{array}$ & & & $\begin{array}{l}0.014^{* *} \\
(0.071)\end{array}$ & \\
\hline Individual Owner & & $\begin{array}{l}-0.078 \\
(0.062) \\
\end{array}$ & & & $\begin{array}{l}-0.000 \\
(0.033) \\
\end{array}$ & & & $\begin{array}{l}0.008 \\
(0.018) \\
\end{array}$ & \\
\hline \multicolumn{10}{|c|}{ Changes in capital structure } \\
\hline $\begin{array}{l}\text { Liabilities/assets } \\
\text { Bank loans/assets }\end{array}$ & & $\begin{array}{l}0.142 \\
(0.127) \\
-0.370^{* *} \\
(0.118) \\
\end{array}$ & & & $\begin{array}{l}0.018 \\
(0.029) \\
-0.008 \\
(0.013) \\
\end{array}$ & & & $\begin{array}{l}0.027 \\
(0.024) \\
-0.012 \\
(0.011) \\
\end{array}$ & \\
\hline $\begin{array}{l}\text { Constant } \\
\text { Industrial dummies } \\
\text { Control for missing }\end{array}$ & & $\begin{array}{l}0.019 \\
(0.014) \\
\text { YES } \\
\text { YES } \\
\end{array}$ & & & $\begin{array}{l}-0.001 \\
(0.012) \\
\text { YES } \\
\text { YES } \\
\end{array}$ & & & $\begin{array}{l}-0.014 \\
(0.011) \\
\text { YES } \\
\text { YES } \\
\end{array}$ & \\
\hline $\begin{array}{l}\mathrm{R}^{2} \text { adjusted } \\
\text { No. of observations }\end{array}$ & & $\begin{array}{l}0.118 \\
1646 \\
\end{array}$ & & & $\begin{array}{l}0.079 \\
773 \\
\end{array}$ & & & $\begin{array}{l}0.045 \\
1082 \\
\end{array}$ & \\
\hline State controlled & 31 & 115 & 115 & 4 & 13 & 13 & 6 & 34 & 34 \\
\hline Privately held & 84 & 1531 & 1531 & 769 & 769 & 769 & 1076 & 1048 & 1048 \\
\hline
\end{tabular}

Note: Categories of the state control are FNM Direct (C1), FNM Direct plus Golden share (C2), and State pyramid plus Golden share (C3). Standard errors are given in parentheses. ${ }^{* *},{ }^{* *}$, and ${ }^{*}$ denote statistical significance of coefficients at 1,5 , and $10 \%$. 
Table 8. Performance: Operating profit/total assets (25\% control)

\begin{tabular}{|c|c|c|c|c|c|c|c|c|c|}
\hline \multirow{2}{*}{ Variable } & \multicolumn{3}{|c|}{$1998-2000$} & \multicolumn{3}{|c|}{$2001-2003$} & \multicolumn{3}{|c|}{$2004-2005$} \\
\hline & C1 & $\mathrm{C} 2$ & C3 & C1 & $\mathrm{C} 2$ & $\mathrm{C} 3$ & C1 & $\mathrm{C} 2$ & $\mathrm{C3}$ \\
\hline \multicolumn{10}{|c|}{ Initial post privatization ownership } \\
\hline State & $\begin{array}{l}-0.002 \\
(0.019)\end{array}$ & $\begin{array}{l}-0.001 \\
(0.018)\end{array}$ & $\begin{array}{l}0.043 \\
(0.035)\end{array}$ & $\begin{array}{l}-0.013 \\
(0.039)\end{array}$ & $\begin{array}{l}-0.002 \\
(0.031)\end{array}$ & $\begin{array}{l}0.110 \\
(0.098)\end{array}$ & $\mid \begin{array}{l}-0.024 \\
(0.018)\end{array}$ & $\begin{array}{l}0.024^{*} \\
(0.013)\end{array}$ & $\begin{array}{l}0.075^{*} \\
(0.041)\end{array}$ \\
\hline Financial Co. & & $\begin{array}{l}-0.022 \\
(0.021)\end{array}$ & & & $\begin{array}{l}-0.031 \\
(0.054)\end{array}$ & & & $\begin{array}{l}0.011 \\
(0.017)\end{array}$ & \\
\hline Big industrial Co. & & 0.006 & & & $0.025 * *$ & & & $0.033 * *$ & \\
\hline & & -0.003 & & & 0.019 & & & 0.016 & \\
\hline Inaiviaual uwner & & $(0.028)$ & & & $(0.035)$ & & & $(0.030)$ & \\
\hline \multicolumn{10}{|c|}{ Subsequent changes in ownership (w.r. to the first period: 1995-1997) } \\
\hline State & $\begin{array}{l}0.110^{*} \\
(0.061)\end{array}$ & $\begin{array}{l}0.132 * * \\
(0.057)\end{array}$ & $\begin{array}{l}0.138 * * \\
(0.057)\end{array}$ & $\begin{array}{l}0.037^{*} \\
(0.029)\end{array}$ & $\begin{array}{l}0.015^{*} \\
(0.009)\end{array}$ & $\begin{array}{l}0.112^{*} \\
(0.069)\end{array}$ & $\begin{array}{l}-0.056 * * \\
(0.027)\end{array}$ & $\begin{array}{l}0.001 \\
(0.026)\end{array}$ & $\begin{array}{l}0.039 * \\
(0.022)\end{array}$ \\
\hline Financial Co. & & $\begin{array}{l}-0.027 \\
(0.035)\end{array}$ & & & $\begin{array}{l}0.202^{*} \\
(0.116)\end{array}$ & & & $\begin{array}{l}-0.011 \\
(0.021)\end{array}$ & \\
\hline Big industrial Co. & & $\begin{array}{l}-0.015 \\
(0.014)\end{array}$ & & & $\begin{array}{l}0.004^{*} \\
(0.003)\end{array}$ & & & $\begin{array}{l}0.023^{*} \\
(0.014)\end{array}$ & \\
\hline Individual Owner & & $\begin{array}{l}-0.066 \\
(0.061)\end{array}$ & & & $\begin{array}{l}0.011 \\
(0.029)\end{array}$ & & & $\begin{array}{l}0.019 \\
(0.017)\end{array}$ & \\
\hline \multicolumn{10}{|c|}{ Changes in capital structure } \\
\hline $\begin{array}{l}\text { Liabilities/assets } \\
\text { Bank loans/assets }\end{array}$ & & $\begin{array}{l}0.145 \\
(0.126) \\
-0.369 * * \\
(0.117) \\
\end{array}$ & & & $\begin{array}{l}-0.007 \\
(0.014) \\
0.118^{* * *} \\
(0.040) \\
\end{array}$ & & & $\begin{array}{l}-0.012 \\
(0.011) \\
0.034^{*} \\
(0.019) \\
\end{array}$ & \\
\hline $\begin{array}{l}\text { Constant } \\
\text { Industrial dummies } \\
\text { Control for missing }\end{array}$ & & $\begin{array}{l}0.011 \\
(0.018) \\
\text { YES } \\
\text { YES } \\
\end{array}$ & & & $\begin{array}{l}-0.020 \\
(0.017) \\
\text { YES } \\
\text { YES } \\
\end{array}$ & & & $\begin{array}{l}-0.031^{* *} \\
(0.016) \\
\text { YES } \\
\text { YES }\end{array}$ & \\
\hline $\begin{array}{l}\mathrm{R}^{2} \text { adjusted } \\
\text { No. of observations }\end{array}$ & & $\begin{array}{l}0.116 \\
1646 \\
\end{array}$ & & & $\begin{array}{l}0.075 \\
773 \\
\end{array}$ & & & $\begin{array}{l}0.051 \\
1082 \\
\end{array}$ & \\
\hline $\begin{array}{l}\text { State controlled } \\
\text { Privately held }\end{array}$ & $\begin{array}{c}60 \\
1586\end{array}$ & $\begin{array}{c}131 \\
1515\end{array}$ & $\begin{array}{c}132 \\
1514\end{array}$ & $\begin{array}{c}4 \\
769\end{array}$ & $\begin{array}{c}13 \\
760\end{array}$ & $\begin{array}{c}13 \\
760\end{array}$ & $\begin{array}{c}7 \\
1075\end{array}$ & $\begin{array}{c}36 \\
1046\end{array}$ & $\begin{array}{c}36 \\
1046\end{array}$ \\
\hline
\end{tabular}

Note: Categories of the state control are FNM Direct (C1), FNM Direct plus Golden share (C2), and State pyramid plus Golden share (C3). Standard errors are given in parentheses. $* * *, * *$, and $*$ denote statistical significance of coefficients at 1,5 , and $10 \%$. 
Table 9. Performance: Sales/total assets (50\% control)

\begin{tabular}{|c|c|c|c|c|c|c|c|c|c|}
\hline \multirow{2}{*}{ Variable } & \multicolumn{3}{|c|}{$1998-2000$} & \multicolumn{3}{|c|}{$2001-2003$} & \multicolumn{3}{|c|}{ 2004-2005 } \\
\hline & C1 & $\mathrm{C} 2$ & $\mathrm{C} 3$ & C1 & $\mathrm{C} 2$ & $\mathrm{C3}$ & C1 & $\mathrm{C} 2$ & $\mathrm{C} 3$ \\
\hline \multicolumn{10}{|c|}{ Initial post privatization ownership } \\
\hline State & $\begin{array}{l}-0.409 \\
(0.292)\end{array}$ & $\begin{array}{l}-0.528 * * \\
(0.135)\end{array}$ & $\begin{array}{l}-0.608 * * \\
(0.214)\end{array}$ & $\begin{array}{l}-0.225 \\
(0.416)\end{array}$ & $\begin{array}{l}-0.501 * * \\
(0.226)\end{array}$ & $\begin{array}{l}-0.892 * * \\
(0.160)\end{array}$ & $\begin{array}{l}-0.704 * * \\
(0.279)\end{array}$ & $\begin{array}{l}-0.875^{* *:} \\
(0.095)\end{array}$ & $\begin{array}{l}-0.92 * * * \\
(0.101)\end{array}$ \\
\hline Financial Co. & \multicolumn{3}{|c|}{$\begin{array}{l}-0.705^{* * *} \\
(0.188)\end{array}$} & \multicolumn{3}{|c|}{$\begin{array}{l}-0.066 \\
(0.600)\end{array}$} & \multicolumn{3}{|c|}{$\begin{array}{l}0.598 \\
(0.916)\end{array}$} \\
\hline Big industrial Co. & \multicolumn{3}{|c|}{$0.288^{* *}$} & \multicolumn{3}{|c|}{$0.442 * * *$} & \multicolumn{3}{|c|}{$0.458 * * *$} \\
\hline \multirow{2}{*}{ Individual Owner } & & $1.234 * * *$ & & \multirow{2}{*}{\multicolumn{3}{|c|}{$\begin{array}{l}0.895^{* * *} \\
(0.234) \\
\end{array}$}} & \multirow{2}{*}{\multicolumn{3}{|c|}{$\begin{array}{l}0.714 * * * \\
(0.127)\end{array}$}} \\
\hline & & $(0.195)$ & & & & & & & \\
\hline \multicolumn{10}{|c|}{ Subsequent changes in ownership (w.r. to the first period: 1995-1997) } \\
\hline State & $\begin{array}{l}-0.039 \\
(0.278)\end{array}$ & $\begin{array}{l}-0.882 \\
(0.646)\end{array}$ & $\begin{array}{l}-0.930 \\
(0.584)\end{array}$ & $\begin{array}{l}0.588 \\
(0.427)\end{array}$ & $\begin{array}{l}0.197 \\
(0.235)\end{array}$ & $\begin{array}{l}-0.212 \\
(0.163)\end{array}$ & $\begin{array}{l}-0.296 \\
(0.298)\end{array}$ & $\begin{array}{l}-0.383^{* *:} \\
(0.108)\end{array}$ & $\begin{array}{l}-0.46 * * * \\
(0.086)\end{array}$ \\
\hline Financial Co. & \multicolumn{3}{|c|}{$\begin{array}{l}-0.673 * * * \\
(0.162)\end{array}$} & & $\begin{array}{l}-0.663^{*} \\
(0.372)\end{array}$ & & & $\begin{array}{l}-0.112 \\
(0.490)\end{array}$ & \\
\hline Big industrial Co. & \multicolumn{3}{|c|}{$\begin{array}{l}0.196 * * \\
(0.087)\end{array}$} & \multicolumn{3}{|c|}{0.112} & \multicolumn{3}{|c|}{$\begin{array}{l}0.044 \\
(0.086)\end{array}$} \\
\hline Individual Owner & & $\begin{array}{l}0.152 \\
(0.185) \\
\end{array}$ & & \multicolumn{3}{|c|}{$(0.200)$} & & $\begin{array}{l}0.327^{* *} \\
(0.160) \\
\end{array}$ & \\
\hline Changes in capital st & ture & & & & & & & & \\
\hline $\begin{array}{l}\text { Liabilities/assets } \\
\text { Bank loans/assets }\end{array}$ & & $\begin{array}{l}-0.149 \\
(0.389) \\
-0.005 \\
(0.334) \\
\end{array}$ & & & $\begin{array}{l}0.143 \\
(0.238) \\
-0.067 \\
(0.108) \\
\end{array}$ & & & $\begin{array}{l}0.032 \\
(0.048) \\
-0.016 \\
(0.022) \\
\end{array}$ & \\
\hline $\begin{array}{l}\text { Constant } \\
\text { Industrial dummies } \\
\text { Control for missing }\end{array}$ & & $\begin{array}{l}0.065 \\
(0.120) \\
\text { YES } \\
\text { YES } \\
\end{array}$ & & & $\begin{array}{l}0.002 \\
(0.192) \\
\text { YES } \\
\text { YES } \\
\end{array}$ & & & $\begin{array}{l}-0.005 \\
(0.275) \\
\text { YES } \\
\text { YES }\end{array}$ & \\
\hline $\begin{array}{l}\mathrm{R}^{2} \text { adjusted } \\
\text { No. of observations } \\
\end{array}$ & & $\begin{array}{l}0.131 \\
1646 \\
\end{array}$ & & & $\begin{array}{l}0.068 \\
773 \\
\end{array}$ & & & $\begin{array}{l}0.052 \\
1082 \\
\end{array}$ & \\
\hline State controlled & 31 & 115 & 115 & 4 & 13 & 13 & 6 & 34 & 34 \\
\hline Privately held & 1615 & 1531 & 1531 & 769 & 769 & 769 & 1076 & 1048 & 1048 \\
\hline
\end{tabular}

Note: Categories of the state control are FNM Direct (C1), FNM Direct plus Golden share (C2), and State pyramid plus Golden share (C3). Standard errors are given in parentheses. $* * *, * *$, and $*$ denote statistical significance of coefficients at 1, 5, and $10 \%$. 
Table 10. Performance: Sales/total assets ( $25 \%$ control)

\begin{tabular}{|c|c|c|c|c|c|c|c|c|c|}
\hline \multirow{2}{*}{ Variable } & \multicolumn{3}{|c|}{$1998-2000$} & \multicolumn{3}{|c|}{$2001-2003$} & \multicolumn{3}{|c|}{ 2004-2005 } \\
\hline & C1 & $\mathrm{C} 2$ & $\mathrm{C} 3$ & C1 & $\mathrm{C} 2$ & $\mathrm{C} 3$ & C1 & $\mathrm{C} 2$ & $\mathrm{C3}$ \\
\hline \multicolumn{10}{|c|}{ Initial post privatization ownership } \\
\hline State & $\begin{array}{l}-0.263^{* *} \\
(0.130)\end{array}$ & $\begin{array}{l}-0.052 \\
(0.097)\end{array}$ & $\begin{array}{l}-0.445^{* *} \\
(0.115)\end{array}$ & $\begin{array}{l}-0.286^{*} \\
(0.162)\end{array}$ & $\begin{array}{l}-0.221^{* *} \\
(0.103)\end{array}$ & $\begin{array}{l}-0.695^{* *} \\
(0.107)\end{array}$ & $\begin{array}{l}-0.335^{* *} \\
(0.105)\end{array}$ & $\begin{array}{l}-0.110 * \\
(0.066)\end{array}$ & $\begin{array}{l}-0.69 * * * \\
(0.069)\end{array}$ \\
\hline Financial Co. & \multicolumn{3}{|c|}{$\begin{array}{l}-0.503^{* * *} \\
(0.132)\end{array}$} & \multicolumn{3}{|c|}{-0.414} & \multicolumn{3}{|c|}{$\begin{array}{l}-0.201 \\
(0.275)\end{array}$} \\
\hline Big industrial Co. & \multicolumn{3}{|c|}{0.065} & & $0.309 * *$ & & \multicolumn{3}{|c|}{$0.407 * * *$} \\
\hline Individual Owner & & $\begin{array}{l}0.901 * * * \\
(0.160)\end{array}$ & & \multicolumn{3}{|c|}{$\begin{array}{l}0.788 * * * \\
(0.156)\end{array}$} & \multicolumn{3}{|c|}{$\begin{array}{l}0.766 * * * \\
(0.104)\end{array}$} \\
\hline \multicolumn{10}{|c|}{ Subsequent changes in ownership (w.r. to the first period: 1995-1997) } \\
\hline State & $\begin{array}{l}0.196 \\
(0.143)\end{array}$ & $\begin{array}{l}-0.770 \\
(0.647)\end{array}$ & $\begin{array}{l}-0.811 \\
(0.587)\end{array}$ & $0.040 * * * 0.052$ & $\begin{array}{l}0.052 \\
(0.157)\end{array}$ & \multirow[t]{4}{*}{$\begin{array}{l}-0.064 \\
(0.128)\end{array}$} & \multirow[t]{4}{*}{$\begin{array}{l}-0.017 \\
(0.149)\end{array}$} & \multirow{4}{*}{$\begin{array}{l}-0.131 \\
(0.099) \\
-0.447^{*} \\
(0.264) \\
0.044 \\
(0.083) \\
0.261 \\
(0.161)\end{array}$} & \multirow[t]{4}{*}{$\begin{array}{l}-0.24 * * * \\
(0.080)\end{array}$} \\
\hline Financial Co. & & $\begin{array}{l}-0.566 * * \\
(0.162)\end{array}$ & & & $\begin{array}{l}-0.652 * \\
(0.333)\end{array}$ & & & & \\
\hline Big industrial Co. & & $\begin{array}{l}0.219 * * \\
(0.089)\end{array}$ & & & $\begin{array}{l}0.136^{*} \\
(0.077)\end{array}$ & & & & \\
\hline Individual Owner & & $\begin{array}{l}-0.018 \\
(0.185)\end{array}$ & & & $\begin{array}{l}0.205 \\
(0.206)\end{array}$ & & & & \\
\hline \multicolumn{10}{|c|}{ Changes in capital structure } \\
\hline $\begin{array}{l}\text { Liabilities/assets } \\
\text { Bank loans/assets }\end{array}$ & \multicolumn{3}{|c|}{$\begin{array}{l}-0.156 \\
(0.395) \\
0.003 \\
(0.337) \\
\end{array}$} & \multicolumn{3}{|c|}{$\begin{array}{l}0.090 \\
(0.239) \\
-0.043 \\
(0.108) \\
\end{array}$} & \multicolumn{3}{|c|}{$\begin{array}{l}0.024 \\
(0.062) \\
-0.013 \\
(0.028)\end{array}$} \\
\hline $\begin{array}{l}\text { Constant } \\
\text { Industrial dummies } \\
\text { Control for missing }\end{array}$ & & $\begin{array}{l}0.065 \\
(0.120) \\
\text { YES } \\
\text { YES } \\
\end{array}$ & & & $\begin{array}{l}0.002 \\
(0.192) \\
\text { YES } \\
\text { YES } \\
\end{array}$ & & & $\begin{array}{l}-0.005 \\
(0.275) \\
\text { YES } \\
\text { YES } \\
\end{array}$ & \\
\hline $\begin{array}{l}\mathrm{R}^{2} \text { adjusted } \\
\text { No. of observations }\end{array}$ & & $\begin{array}{l}0.092 \\
1646 \\
\end{array}$ & & & $\begin{array}{l}0.067 \\
773 \\
\end{array}$ & & & $\begin{array}{l}0.045 \\
1082 \\
\end{array}$ & \\
\hline $\begin{array}{l}\text { State controlled } \\
\text { Privately held }\end{array}$ & $\begin{array}{c}60 \\
1586\end{array}$ & $\begin{array}{c}131 \\
1515\end{array}$ & $\begin{array}{c}132 \\
1514\end{array}$ & $\begin{array}{c}4 \\
769\end{array}$ & $\begin{array}{c}13 \\
760\end{array}$ & $\begin{array}{c}13 \\
760\end{array}$ & $\begin{array}{c}7 \\
1075\end{array}$ & $\begin{array}{c}36 \\
1046\end{array}$ & $\begin{array}{c}36 \\
1046\end{array}$ \\
\hline
\end{tabular}

Note: Categories of the state control are FNM Direct (C1), FNM Direct plus Golden share (C2), and State pyramid plus Golden share (C3). Standard errors are given in parentheses. $* * *, * *$, and $*$ denote statistical significance of coefficients at 1, 5, and $10 \%$. 


\section{CESifo Working Paper Series}

for full list see www.cesifo-group.org/wp

(address: Poschingerstr. 5, 81679 Munich, Germany, office@cesifo.de)

2741 Yan Dong and John Whalley, A Third Benefit of Joint Non-OPEC Carbon Taxes: Transferring OPEC Monopoly Rent, August 2009

2742 Valentina Bosetti, Carlo Carraro and Massimo Tavoni, Climate Change Mitigation Strategies in Fast-Growing Countries: The Benefits of Early Action, August 2009

2743 Christina Felfe, The Willingness to Pay for Job Amenities: Evidence from Mothers' Return to Work, August 2009

2744 Jörg Franke, Christian Kanzow, Wolfgang Leininger and Alexandra Väth, Effort Maximization in Asymmetric N-Person Contest Games, August 2009

2745 Bruno S. Frey and Paolo Pamini, Making World Heritage Truly Global: The Culture Certificate Scheme, August 2009

2746 Frank N. Caliendo, Is Social Security behind the Collapse of Personal Saving?, August 2009

2747 Caterina Liesegang and Marco Runkel, Corporate Income Taxation of Multinationals and Fiscal Equalization, August 2009

2748 Chrysovalantou Milliou and Apostolis Pavlou, Upstream Horizontal Mergers and Efficiency Gains, August 2009

2749 Rüdiger Pethig and Christian Wittlich, Interaction of Carbon Reduction and Green Energy Promotion in a Small Fossil-Fuel Importing Economy, August 2009

2750 Kai Carstensen, Oliver Hülsewig and Timo Wollmershäuser, Monetary Policy Transmission and House Prices: European Cross-country Evidence, August 2009

2751 Olaf Posch, Explaining Output Volatility: The Case of Taxation, August 2009

2752 Beatrice Scheubel, Daniel Schunk and Joachim Winter, Don't Raise the Retirement Age! An Experiment on Opposition to Pension Reforms and East-West Differences in Germany, August 2009

2753 Daniel G. Arce, Dan Kovenock and Brian Roberson, Suicide Terrorism and the Weakest Link, August 2009

2754 Mario Larch and Wolfgang Lechthaler, Comparative Advantage and Skill-Specific Unemployment, August 2009

2755 Horst Raff and Nicolas Schmitt, Buyer Power in International Markets, August 2009 
2756 Seppo Kari, Hanna Karikallio and Jukka Pirttilä, The Impact of Dividend Taxation on Dividends and Investment: New Evidence Based on a Natural Experiment, August 2009

2757 Mirco Tonin and Michael Vlassopoulos, Disentangling the Sources of Pro-social Behavior in the Workplace: A Field Experiment, August 2009

2758 Nicole Grunewald and Inmaculada Martínez-Zarzoso, Driving Factors of Carbon Dioxide Emissions and the Impact from Kyoto Protocol, August 2009

2759 Yu-Fu Chen and Michael Funke, Booms, Recessions and Financial Turmoil: A Fresh Look at Investment Decisions under Cyclical Uncertainty, August 2009

2760 Jan-Egbert Sturm and Jakob de Haan, Does Central Bank Communication really Lead to better Forecasts of Policy Decisions? New Evidence Based on a Taylor Rule Model for the ECB, August 2009

2761 Larry Karp, Sacrifice, Discounting and Climate Policy: Five Questions, August 2009

2762 Marianna Belloc and Samuel Bowles, International Trade, Factor Mobility and the Persistence of Cultural-Institutional Diversity, August 2009

2763 Charles Noussair and Fangfang Tan, Voting on Punishment Systems within a Heterogeneous Group, August 2009

2764 Birgit Bednar-Friedl and Karl Farmer, Internationally Coordinated Emission Permit Policies: An Option for Withdrawers from the Kyoto Protocol?, August 2009

2765 Pierre M. Picard and David E. Wildasin, Labor Market Pooling, Outsourcing and Labor Contracts, August 2009

2766 Stefan Voigt and Lorenz Blume, The Economic Effects of Federalism and Decentralization - A Cross-Country Assessment, August 2009

2767 David S. Jacks, Christopher M. Meissner and Dennis Novy, Trade Booms, Trade Busts, and Trade Costs, August 2009

2768 Mario Jametti and Thomas von Ungern-Sternberg, Hurricane Insurance in Florida, August 2009

2769 Alessandro Balestrino, Kind of Black: The Musicians' Labour Market in Italy, August 2009

2770 Yosr Abid Fourati and Cathal O’Donoghue, Eliciting Individual Preferences for Pension Reform, August 2009

2771 Christian Breuer and Chang Woon Nam, VAT on Intra-Community Trade and Bilateral Micro Revenue Clearing in the EU, August 2009

2772 Choudhry Tanveer Shehzad, Jakob De Haan and Bert Scholtens, Growth and Earnings Persistence in Banking Firms: A Dynamic Panel Investigation, August 2009 
2773 Erdal Yalcin, Uncertain Productivity Growth and the Choice between FDI and Export, August 2009

2774 Klaus Abberger, Wolfgang Nierhaus and Shynar Shaikh, Findings of the Signal Approach for Financial Monitoring in Kazakhstan, September 2009

2775 Sascha O. Becker, Francesco Cinnirella and Ludger Woessmann, The Trade-off between Fertility and Education: Evidence from before the Demographic Transition, September 2009

2776 Thomas Aronsson and Erkki Koskela, Optimal Income Taxation, Outsourcing and Policy Cooperation in a Dynamic Economy, September 2009

2777 Joel Slemrod, Old George Orwell Got it Backward: Some Thoughts on Behavioral Tax Economics, September 2009

2778 Cagri Seda Kumru and Athanasios C. Thanopoulos, Social Security Reform and Temptation, September 2009

2779 Alessandro Bucciol and Roel M. W. J. Beetsma, Inter- and Intra-generational Consequences of Pension Buffer Policy under Demographic, Financial and Economic Shocks, September 2009

2780 Eduardo Strube and Marcelo Resende, Complementarity of Innovation Policies in the Brazilian Industry: An Econometric Study, September 2009

2781 Henry Tulkens and Vincent van Steenberghe, "Mitigation, Adaptation, Suffering": In Search of the Right Mix in the Face of Climate Change, September 2009

2782 Maria L. Loureiro, Anna Sanz-de-Galdeano and Daniela Vuri, Smoking Habits: Like Father, Like Son, Like Mother, Like Daughter, September 2009

2783 Momi Dahan, Tehila Kogut and Moshe Shalem, Do Economic Policymakers Practice what they Preach? The Case of Pension Decisions, September 2009

2784 Eytan Sheshinski, Uncertain Longevity and Investment in Education, September 2009

2785 Nannette Lindenberg and Frank Westermann, How Strong is the Case for Dollarization in Costa Rica? A Note on the Business Cycle Comovements with the United States, September 2009

2786 Leif Danziger, Noncompliance and the Effects of the Minimum Wage on Hours and Welfare in Competitive Labor Markets, September 2009

2787 Gerlinde Fellner, Rupert Sausgruber and Christian Traxler, Testing Enforcement Strategies in the Field: Legal Threat, Moral Appeal and Social Information, September 2009

2788 Gabriel J. Felbermayr, Mario Larch and Wolfgang Lechthaler, Unemployment in an Interdependent World, September 2009 
2789 Sebastian G. Kessing, Federalism and Accountability with Distorted Election Choices, September 2009

2790 Daniel Gros, Global Welfare Implications of Carbon Border Taxes, September 2009

2791 Louis N. Christofides, Michael Hoy and Ling Yang, The Gender Imbalance in Participation in Canadian Universities (1977-2005), September 2009

2792 Jan K. Brueckner and Robert W. Helsley, Sprawl and Blight, September 2009

2793 Vidar Christiansen and Stephen Smith, Externality-correcting Taxes and Regulation, September 2009

2794 John Beirne, Guglielmo Maria Caporale, Marianne Schulze-Ghattas and Nicola Spagnolo, Global and Regional Spillovers in Emerging Stock Markets: A Multivariate GARCH-in-mean Analysis, September 2009

2795 Rüdiger Pethig and Frieder Kolleß, Asymmetric Capital-Tax Competition, Unemployment and Losses from Capital Market Integration, September 2009

2796 Ngo Van Long, Horst Raff and Frank Stähler, Innovation and Trade with Heterogeneous Firms, September 2009

2797 Margit Osterloh and Bruno S. Frey, Research Governance in Academia: Are there Alternatives to Academic Rankings?, September 2009

2798 Thiess Buettner and Clemens Fuest, The Role of the Corporate Income Tax as an Automatic Stabilizer, September 2009

2799 Annette Alstadsæter, Measuring the Consumption Value of Higher Education, September 2009

2800 Peter Friedrich, Chang Woon Nam and Janno Reiljan, Local Fiscal Equalization in Estonia: Is a Reform Necessary?, September 2009

2801 Evžen Kočenda and Jan Hanousek, State Ownership and Control in the Czech Republic, September 2009 